University of Louisville

ThinkIR: The University of Louisville's Institutional Repository

$5-2020$

\title{
Afrosonic noise: a transnational Black Feminist musicological study of global Black joy in Black North American rock music and Afro Argentinian music performance.
}

Jerika M Jones

University of Louisville

Follow this and additional works at: https://ir.library.louisville.edu/etd

Part of the Aesthetics Commons, African American Studies Commons, American Popular Culture Commons, Ethnomusicology Commons, Feminist Philosophy Commons, and the Music Performance Commons

\section{Recommended Citation}

Jones, Jerika M, "Afrosonic noise: a transnational Black Feminist musicological study of global Black joy in Black North American rock music and Afro Argentinian music performance." (2020). Electronic Theses and Dissertations. Paper 3457.

https://doi.org/10.18297/etd/3457

This Master's Thesis is brought to you for free and open access by ThinkIR: The University of Louisville's Institutional Repository. It has been accepted for inclusion in Electronic Theses and Dissertations by an authorized administrator of ThinkIR: The University of Louisville's Institutional Repository. This title appears here courtesy of the author, who has retained all other copyrights. For more information, please contact thinkir@louisville.edu. 
AFROSONIC NOISE:A TRANSNATIONAL BLACK FEMINIST MUSICOLOGICAL STUDY OF GLOBAL BLACK JOY IN BLACK NORTH AMERICAN ROCK MUSIC AND AFRO ARGENTINIAN MUSIC PERFORMANCE

$$
\text { By: }
$$

Jerika M. Jones

BA in Psychology, 2014

BA in Philosophy, 2016

MA in Women’s, Gender, and Sexuality Studies, 2020

\author{
A Thesis \\ Submitted to the Faculty of \\ the College of Arts and Sciences of \\ the University of Louisville in Partial Fulfillment of \\ the Requirements for the Degree of
}

Master of Arts in Women’s, Gender, and Sexuality Studies

Women's, Gender, and Sexuality Studies

University of Louisville

Louisville, Kentucky

May 2020 
Copyright 2020 by Jerika M. Jones

All rights reserved 

AFROSONIC NOISE:A TRANSNATIONAL BLACK FEMINIST MUSICOLOGICAL STUDY OF GLOBAL BLACK JOY IN BLACK NORTH AMERICAN ROCK MUSIC AND AFRO ARGENTINIAN MUSIC PERFORMANCE

\author{
By \\ Jerika Jones \\ B.A.,University of Louisville, 2014 \\ B.A., University of Louisville, 2016 \\ M.A., University of Louisville \\ A Thesis Approved on
}

April 13, 2020

by the following Thesis Committee:

Dr. Kalia Adia Story, Chair

Simona Bertacco

Michael Brandon McCormick 


\section{ACKNOWLEDGEMENTS}

I want to give a very big and special thank you to my newfound extended family in Buenos Aires, Argentina—who have taught me more about myself than I possibly could have learned on my own. I also want to send love and light to Dr. Kaila Story and Dr. Simona Bertacco. You all are the people who have helped me grow as a scholar, who expected me to do and be better, held me accountable to my success and have opened so many doors for me. I also want to thank Dr. Brandon McCormack, ally and recent mentor, who helped oversee my thesis process.

I also want to sincerely thank all Frederico Pita, Isabel, Maria, and all the Afro Argentines who welcomed me into their community, trusted me with their stories, and participated in editing this work to ensure I captured their Afro Argentinian experience accurately 


\begin{abstract}
AFROSONIC NOISE:A TRANSNATIONAL BLACK FEMINIST MUSICOLOGICAL STUDY OF GLOBAL BLACK JOY IN BLACK NORTH AMERICAN ROCK MUSIC AND AFRO ARGENTINIAN MUSIC PERFORMANCE

Jerika Jones
\end{abstract}

April 13, 2020

I have decided that my academic mission, at this juncture at least, is to find common links between 2 groups of people that have come to know themselves through paralleling but colonially different environments. Perhaps it is wise for me to explore the similarities between Afro Argentine Black Music and African North American Music in closer ethnomusicological detail using feminist praxis—after all both communities are part of the African Diaspora and producing Black music. I do this by reconstructing a very limited genealogy of Black Femme's and their contribution to their respective musical communities. I draw parallels between the global African Diasporic communities of the Americas to connect, but not conflate, the histories of Black Femme performance in music and their contributions to Black Feminist discourse. I argue that Black joy is a musicological and essential element that is unique to and shared between Afro Argentinian and Black North American underground Rock music, as Black joy is one of the phenomenological elements of identity that our distant communities share alongside our antagonistic existences with our respective colonial powers, protest, and resistance. I anchor my argument in Argentinian Feminist Performance theorist Diane Taylor's work entitled The Archive and the Repertoire and Black Feminist theorist Daphne Brook’s 
work entitled Afro Sonic Feminist Praxis. Black joy is not only fundamental to the performance of Black music in the African Diaspora, but it is also an analytic tool that is methodologically significant and crucial to understanding these shared global identities. I use Black joy as synonymous with Afro Sonic Noise and explore it alongside traditional musicological elements of underground Rock music such as tone and timbre to create a sonic picture of transnational and feminist Afro Sonic Noise. 
TABLE OF CONTENTS



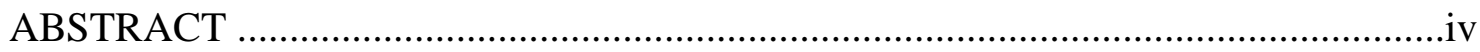

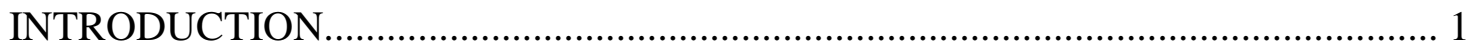

CHAPTER 1: BLACK ROOTS: A START OF A BLACK AND FEMINIST

AUTOETHNOGRAPHIC GENEALOGY OF EARLY ROCK AND ROLL MUSIC IN

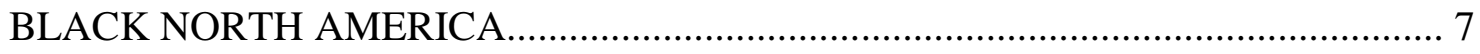

THE BLACK ROOTS OF ROCK AND ROLL.............................. 11

BIG MAMA THORTON............................................. 14

BIG MAMA THORTON AND BLACK FEMINIST THOUGHT.............18

CHAPTER 2: TRANSNATIONAL BLACK FEMME IDENTITIES IN MUSIC:

EXPLORING THE SHARED IDENTITIES BETWEEN BLACK NORTH AMERICAN AND AFRO ARGENTINE FEMMES....................................................................25

AFRO ARGENTINA: HISTORY AND CULTURE...................... 26

AFRO ARGENTINA: RELIGION, GENDER, AND MYTH................ 34

RADICAL BLACK FEMMES IN ARGENTINA’S POPULAR MUSIC........ 37

BLACKNESS IN MUSIC: SPIRIT OF REBELLION....................... 46

AFRO LATINIDAD ..............................................47

GENRE IS INSIGNIFICANT, MOSTLY............................ 51

CHAPTER 3: GLOBAL BLACK JOY AND AFRO SONIC NOISE: A SONIC

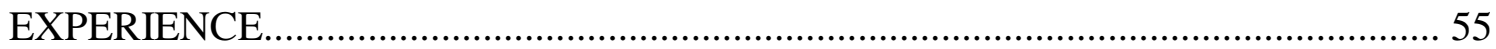

CHAPTER 4; A STRANGERS SEE ONLY WHAT SHE KNOWS: LIMITATIONS OF

TRANSNATIONAL MUSICOLOGY ..................................... 74 


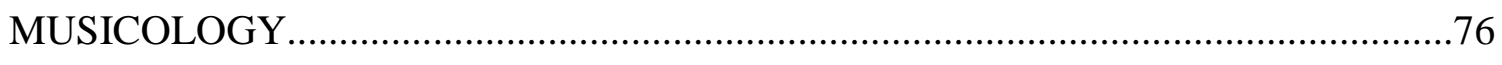

MUSIC IS CHANGING ................................................ 79

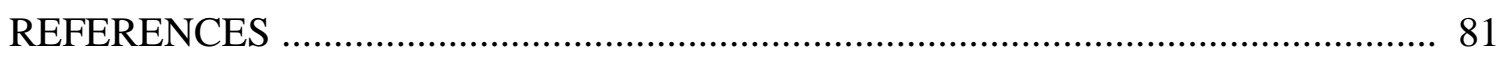

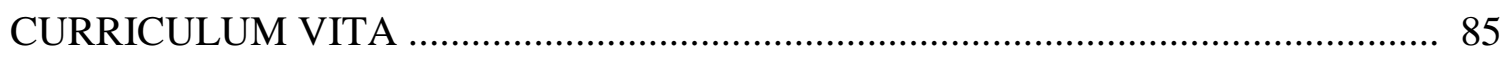




\section{INTRODUCTION}

Music is often a subject that has been well examined by scholars in various fields. Musicology as a discipline has been at the forefront of much of the musical studies, alongside other traditions like music history, philosophy, politics, and perceptual science, as separate approaches to understanding what music does for society. These traditions have contributed to some understanding of music.

Musicological study in the Americas have relied heavily on dominant discourse around culture, beauty, and emotions. As a result, our evaluations of music tend to prioritize western and euro-centric perspectives, value judgments of aesthetic worth, and generally hinge upon a complacency or complicities in toned down cultural imperialism—regardless of the intention of the researcher. It is also difficult to find musicological research that does fair justice to music-makers whose identities fall within the margins and in contra- or counter-modern spaces. I find that musicological scholarship rarely does justice to the particularities of a particular music performance as a reflection of a community's culture and its people's social history as a unit which points to an epistemology of shared identity.

My aim is to take a postcolonial approach to rediscover the roots of African American diasporic music focusing specifically on Rock and Roll and other music genres which have historically been crafted and perfected by Black Femme music-makers in the fartherest corners of the African American and Black Diaspora-- Black North America 
and Afro Agentina. I connect these two groups of people by examining their shared historically and musicological patterns to answer my ultimate question: what is the shared sound of blackness in Black North American and Afro Argentine music? I center the Black femme experience and its cultural products, although my project's conclusion can arguably be applied across the Black experience as a whole to some degree.

My project is a bit unusual in that I approach my study of music using a performative approach which treats music as the subject and leads to an understanding of music as a whole entanglement of the embodied history of a group of people , their affect toward and affinity for a particular sound, their musical composition, identity, and aesthetic quality. This ideal approach, as cultural products such as music are arguably inseparable from the time, place, and persons who have created them.

I am fairly certain that this project’s informative quirks are mostly due to my dedication to Black feminist praxis. I center myself and my experience navigating Black North America as a Black Femme as well as traveling to Buenos Aires, Argentina in order to collect oral history from music makers in Villa Crespo, a historically Afro Argentine barrío within Buenos Aires. I am also a classically trained cellist and a bass guitarist and my experiential expertise of music, music theory, and performance which spans over 20 years also informs this work. I rely heavily on my own experience and training to identify and isolate musical significance and musically congruent sounds, vocalizations, and other theoretical elements that pertain specifically to music theory. I utilize my experiences in both classical and pop music spaces in order to discuss motivations and concepts through my own personal narrative while doing some creative storytelling. I begin to question the relationship and locatibility of Black femme-ness in 
the social narrative of music performance. I highlight African American femme musicmakers as discourse markers by exploring who they were, what they represented, the sounds that they created, and their other legacies.

I push the limitations of locatibility by traveling to Buenos Aires, Argentina and exploring the social history of music in underground Afro Argentina. I use oral histories that I performed with local musicians in order to reveal the musical social histories of Afro Argentina. I use personal narratives to highlight the similarities, and some differences, of the African American Diaspora to establish a socio-cultural connection between these two populations based on musicological, colonial, political and therefore performative similarity. I aim to entangle the discourses as Black North American and Black South America represent different branches of colonial America with enough care to not conflate the experience of either group of people. This leads me to the heart of my thesis , which aims to explore Afro Sonic Noise quality that connects to the African American Diaspora.

My project uses me as the starting point for this genealogy. I explore discourses surrounding a particular person thematically rather than chronologically. I also explore conceptual frameworks as they relate to the themes of the section, which to some individuals, can feel a bit sprawling or perhaps unfocused. However, I do this intentionally as I intend to preserve the entanglement of the person, place, time, music, and sound. I have carefully chosen auto-ethnomusicological frameworks that are congenial with identity theories, epistemologies, and sound studies in such a way that the theories build upon one another as I move through the African American Diaspora. 
There is a distinct presence of affect within this project. This should not come as a surprise, as music often produces feelings for those who create it and for the listener. In some respects, I suppose that I can consider myself using an affective autoethnomusicological approach for performance studies-- although I admit that I have not fully fleshed out what this approach is at this time. Strangely, centering affect in both systemic musicological performance studies and Black feminist studies is not a new phenomenon. However, melding the two disciplines is a less common practice.

I make two contributions to the Black Feminist Musicological study. The first contribution is that I have begun to formulate a new way approaching musicological study by using an affective autoethnomusicological Black feminist approach to understanding music as a significant access point for performance study and music theory combined. My second contribution is that I use the groundwork provided by Argentinian Performance theorist Diana Taylor and her concept of performance and cultural memory as well as Black Feminist Performance theorist and musicologist Daphne Brooks’ North Black North American-centric theory of Afro Sonic Noise to intertwine to sonic contributions of the American Diaspora.

In the first chapter, Black Roots: A Start of A Black Feminist Autoethnographic Genealogy of Early Rock and Roll Music in North America, I build my motivation for this project. I use myself as the initial subject to begin unraveling theories that have contributed to Black Feminist praxis. I then shift my focus to Willie Mae "Big Mama " Thorton who is considered the "Godmama of Rock and Roll”. Willie Mae Thorton is considered to be the most prolific of the Foremama's of Rock and Roll music in North America and serves as a starting point for this project. I perform lyrical analysis on 
Hound Dog, her biggest hit record, in order to glean some sort of understanding of how she locates herself within the Black feminists thought. I lean on Angela Davis’ genealogical work in Blues Legacies and Black Feminism as well as Patricia Hill Collin's work in Black Feminist Epistemology to understand the connection between Black feminist discourse on identity, music as feminist action, and the entanglement of histories, language, and colonial culture.

In the second chapter, Transnational Black Feminist Identities in Music: Exploring the Shared Identities between Black North American and Afro Argentinian Femmes, I share my experiences of traveling through Buenos Aires, Argentina. Sharing what I learned from my time in Buenos Aires, Argentina from the Afro Argentine musicmakers and community activists I met. I explore the social history of Afro Argentine musics, how they sound, the Black Femmes who performed them, and the significance of these performances to the Afro Argentine population in Buenos Aires. Ultimately drawing a connection between Black North American underground Rock Music and Afro Argentinian music. I deconstruct both populations by focusing on the role of "the soul” of their music, which is directly connected to the sonic recognition of Blackness.

In the third chapter, I explore Black music in the American Diaspora in closer sonic and compositional detail. I connect the "soul" as being the expression and recognition of Black Joy or the lack thereof. I stretch Brooks' idea of Afro Sonic noise across the Americas. Using the life story of Rita Morena, Afro Argentine singer and Black North American guitarist Elizabeth "Libba” Cotton to connect not only Afro Sonic noise to disparate communities in the African American Diaspora but to also explore this as another point of entanglement of discourses. 
In the fourth and final chapter, A Stranger Sees Only What She Knows:

Limitations of Transnational Ethnomusicology, I return to the beginning of this work by examining my relationship to the histories that I sought to explore. I question the underlying assumptions that I make as a formally educated Black Femme, navigating through my own intersections of privilege that I inhabit. I explore the limitations of auto ethnography as a potentially inaccurate and historically racist practice and question the ways that I may be participating in the same cultural imperialist agenda that I sought to avoid. 


\section{CHAPTER 1}

\section{BLACK ROOTS: A START OF A BLAKC FEMINIST GENEALOGY OF EARLY ROCK AND ROLL MUSIC IN NORTH AMERICA}

Autoethnography is understood roughly as a form of research that is qualitative in nature where the researcher utilizes of self-reflection in order to recount their personal narrative with the aim of shedding light on their autobiographically-identified social positioning so that they may connect their personal experience to wider cultural, sociopolitical, and philosophical meanings, thought, and discourse. The autoethnographic connections that I make throughout this work has 3 parts: personal, discursive, and genealogical.

I refer to the American Musicological Society for a working definition of Musicology. I paraphrase their definition for the sake of brevity. Musicology is loosely defined as the scholarly study of music, its history and its musical components such as rhythm and timbre etc. This method of studying music is hermeneutical. Musicology seeks to understand music as it relates to the entity or entities that produce it, as it relates to a culture or subculture, its musical style or aesthetic, its musical structure and theory, how it functions as an art form, how it's perceived and the actual performance of musical works as a listener.

I find it worthwhile to note that while musical performance is integral to the components of Musicology, music performance is generally considered to be its own branch of scholarly pursuits and is not directly encompassed by the discipline of 
Musicology. This separation is an attempt to objectively explore the musical work itself. However, it is to the detriment of the history, power, and promise of musicological study to remove music from its performative roots because musical works are inextricably bound to the spectacle of the musical performance. I intentionally keep music-makers intimately bound to their work, their time, and their community.

Autographic Ethnomusicology is at the forefront of musicological study and discourse and has a distinct autobiographical style. Autoethnographic musicology has been fleshed out by Carolyn Ellis and Brydie-Leigh Bartleet in their book Music Ethnographies: Making Autoethnographies sing/ Making Music Personal. They begin their work with extensive self-reflection and it is written in a personal narrative style, phenomenologicall- cogent, dialogue heavy, which is feminist-oriented that I use as a model for the written style of this work. Through their documented dialogue with one another, the scholars outline not only their experiences as conductors for orchestral ensembles but demonstrate how autoethnographic should be valued in the study of music. Their collective work is quite comprehensive. I will not recount the entire book, however, Bartleet and Ellis create a system for musicological study that resembles lyrical sociology in a sense and demonstrate how to use qualitative methods found in sociology in an ethnomusicological way.

For Bartleet and Ellis, the term “autographic ethnomusicology” is defined as a field of study and theory where the primary subject of inquiry is the researcher themselves who serves as the narrator of their experiences as a participant in music production in order to uncover and explore musicological or performative roles that the researcher's race, ethnicity, class, and gender play in the larger discourse of ethnomusicology 
(Barleet, Ellis; 2016; 7). They argue that autoethnography and musicology rely heavily on the socio-political, historical, and cultural context of music and of the entities that have produced them as they relate to their sociopolitical, historical, and culturally situated primary researchers (Bartleet, Ellis;8). They are less focused on the actual performance itself, the musicianship of the performer, and other technicalities of the work..

Bartleet and Ellis' theory gives room to expand upon and explore intersecting identities based on the social positioning of the researcher and how they choose to connect themselves to larger narratives of music. Therefore, I use Sister Outsider by Audre Lorde and Blues Legacies and Black Feminism by Angela Davis in order to position Bartleet and Ellis work within Black Feminist Thought. I especially rely on Davis' work to model how to effectively and authentically connect musical traditions to Black Feminist Thought specifically. While I intend on incorporating a very small portion of the methodological work that Bartleet and Ellis do, I will do so only if it is compatible with Black Feminist Thought as it relates to musicologically-specific research. This is because it is essential for me to rely on the voices of my intellectual foremamas just as I rely on my musical foremamas.

Black feminist thought is not a monolithic discipline and is as varied as other femininst schools of thought. Black Feminism has a longstanding and queered legacy that dates back to before the abolishment of Chattel Slavery. The trend of phenomenological and political critiques seems to be cyclic in nature, meaning that similar questions and critical conversation that took place in the early 20th century parallel similar observations raised in more current day conversations. 
Black Feminist Thought is understood as expansive and markedly intergenerational as well as it functions as an existential conversation around social and political conundrums that Black Femmes face. The social and political questions that fall under this scope include, but are not limited to, personal autonomy, the inessential nature of 'femmehood', exclusion of Black Femmes in Feminist discourse, marginalization of black and queer bodies, Black body politics in general, Black standpoint theories and epistemologies, oppression and liberation, as well as the sexual politics and our relationship to the Black Community as a whole.

Patricia Hill Collins pinpoints four major themes that unite the many seemingly disparate conversations within Black Feminist Thought in her work, Black Feminist Thought: Knowledge, Consciousness, and the Politics of Empowerment, which is anchored by one common feature: Black Feminist Thought. Collins' work centers the experiences of Black women, whom she argues have a contentious and incongruent relationship with society at large. She argues that Black women have both a dialectical and also antagonistic relationship with the White hegemonic world around them. Collins provides an account of Black Feminist Praxis — which is truly a kaleidoscope of different meanings deriving from epistemological insight and a method of inquiry that seeks to connect the socio-political, historical, cultural and dynamic relations between Blackness, womanhood, and the world at large by using analytic tools, theories, and pedagogies in tandem with ethnographic considerations.

For the purposes of this thesis, and given that autoethnographic musicology and Black feminist Praxis both rely heavily on the socio-political, historical, cultural, hermeneutical analysis and understanding, I combine Bartleet and Ellis' framework with 
Collins' and Davis work. I do this on the basis that they are methodologically compatible methods because they center postcolonial approaches to understanding music. Therefore, can be utilized simultaneously to create a more robust critically Black feminst musicological framework. Davis and Collins' contributions ground my work in the phenomenology of my black woman experience and therefore to the sum total of Black feminist thought which is rooted in the voices, experiences, histories, cultures, and historical contexts of Black Femme musicians.

I find it absolutely essential to root my thesis in the real life experience of Black Femme musicians who have preceeded me. Willie Mae Thorton is the historical figure I have chosen to connect myself with in order to access the larger discourse of Blackness in Rock and Roll music as part of the musical genres of the African American diaspora. Although I utilize Willie Mae Thorton as a historical figure, my discussion is primarily thematic and genealogical in nature and will not follow a strictly chronological format. I do this in order to do justice to the nonlinear development of the relationship between Blackness and Rock and Roll.

\section{The Black Roots of Rock and Roll}

I remember the day when I learned the extent of which Black Femmes have been silenced within Rock history. In May of 2015, I was sitting in Central High School’s cafeteria room ready to begin my first volunteer training for Girls Rock Louisville. I was a bit weary of being in the space because, just like the rest of the Rock and Roll spaces in the city, there was sure to be an abundance of very white and very enthusiastic people. 
And I was certain that I would have to navigate a landmine of microaggressions. However, I tend to be charitable to folks when the whim strikes. On this particular day, I decided that these well-meaning people seemed to mean well. I suppose I was feeling generous.

I noticed that there were exactly 8 Black women, of the 60 women total, in the room. They all seemed to be femme-presenting, which was awesome.ut the distinct lack of Black Femmes which I found particularly odd being was that I was sitting in a cafeteria for a school that has historically been attended by black students.

I sat next to a very nice woman from Sweden with blonde locs. She complimented me on my locs and proceeded to tell me about her loc journey. I learned that, apparently, it's a trend in Sweden for Swedes to loc their loosely curled and probably blonde hair, apparently locs are associated with rebellion and very trendy in some Swedish circles.

I told her, “That’s cute.”

She said, "Thank you".

I just looked at her.

And I continued to look at her. In my head I thought to myself, "What the f*** was that? Why is she so proud of her appropriation?”

Shortly after that exchange, I heard an announcement that volunteer training is starting. The lights dimmed. A projector turned on with a PowerPoint slide that said, “Feminist History of Rock and Roll”. A frail, professorial-looking woman introduces herself as an organizer for Girls Rock Louisville-- but was really just the front desk lady. 
They proceeded to tell us what the organization stood for , and it was at this point that I remember tuning out and looking at Facebook briefly, so , I can’t recall how we got into the conversation about Black History and Rock and Roll. But, I do remember hearing the facilitator say, “What do Big Mama Thorton and Elvis have in common”?

I look up. I see this Big Mama Thornton's image next to Elvis Presley's. I sat in my chair stuck on stupid because I had no idea who Big Mama Thornton was or what the point of this question was at all. The rest of the volunteers were silent as well because they had no idea what the connection was either.

After a bit of a pause, the facilitator pulls up a clip. This clip starts with Elvis singing “Hound Dog”. We all started singing along. Hound Dog is one of Elvis’ most iconic songs. After about a minute into the clip, we hear a change. Suddenly the song was slower, sounded grittier and clearly sexual. The instrumentation stayed roughly the same but was somehow-- different. I see Big Mama Thorton singing the original “Hound Dog”. This is the moment when I made the connection. Hound Dog, the song that is accredited to Elvis Presley who is considered to be the "King of Rock and Roll" was actually written for Willie Mae “Big Mama” Thorton. She recorded the song 3 years prior to Elvis’ version and he made money off her record. But this was the first time I had ever heard her name. This Black Queen was usurped by a White King.

It was during this workshop that I learned of the varied and many accounts of Elvis' minstrelsy. I learned about how his sound was lifted from theGospel and Blues of the deep South as well as how Elvis used to visit Black-owned and operated clubs in Memphis Tennessee for the sole purpose of learning how to copy the sound and style. He was proudly lifting music from Black Musicians and white washing them by 
appropriating the sexually liberal aesthetic as well as the performance style, instrumentations, and musical arrangements.

Although Elvis was particularly appropriative of Black and Black Femme music, he is not the only White and mainstream popular music artist to appropiate Black secular and religous music for commercial gain. Big Mama is only one example of the easure of Black femmes and Black culture from music history. Unfortunately, dominant American discourse around music continuously and systematically erases the contributions of Black Femmes in music. By centering Willie Mae's life and career as my first historical figure, I will be able to better explore Black Femme’s musical contributions, tying it to a larger discourse on Blackness, musical history, performance, gender, amd sexuality that can be applied to Black femme music in general.

\section{Big Mama Thorton}

Willie Mae Thorton was born on December 11, 1926 in the rural countryside on the outskirts of Montgomery, Alabama (Malone; Wilson, 2009; 370). She was one of seven children born to her minister Father and a mother who sang in the church choir ( Malone. Wilson; 370). Her mother and father encouraged her to sing in the church choir-which she soon outgrew vocally. She participated in many contests at local churches and began to build a name for herself in the rural Black Communities in Montgomery.

Big mama was a multi-instrumentalist. She developed a bold, strong, secular, and raspy voice at a very young age. She demonstrated a natural gift for playing the drums and the harmonica which she ostensibly learned how to play from her brother, Harp (Fay, 
2009; 184). Big Mama often attributed her successful musicianship to her desire to be close to her brother (Fay, 2009).

When Big Mama was 14 years old, her mother passed away (Spörke, 2015). She began working at local saloons to supplement the income that was lost when her mother died. Thorton started substituting for singers for bands that needed an extra voice (Spörke, 2015). She soon found herself signing regularly at a local bar.

After a few years of singing as a back-up vocalist for local and traveling bands, she attracted the attention of Atlanta music promoter Sammy Green ( Fay, 1990;184-5). There is some discrepancy between the historical accounts of Thorton and Green's initial partnership. However, the most consistent of the accounts is as follows:

“...he heard her win first prize in a local amateur contest; in another she helped his artists move a piano up the club stairs. In any event, in 1941 Thornton joined Green's Georgia-based show, The Hot Harlem Revue, and remained with him for seven years. Billed as the "New Bessie Smith," she sang and danced throughout the southeastern United States. She later acknowledged the influence of artists heard during this time, including Smith, Ma Rainey, Junior Parker, and Memphis Minnie (Spörke, 2015;4).

Around 1948, she settled in Houston. This is where Big Mama created and cultivated the "Texas Blues” (Gaar, 1992; 4). She caught the attention of 2 producers: bandleader Johnny Otis and Don Robey. Robey was particularly interested in Big Mama because she was rumored to play the drums and harmonica as well as sing-- which was extremely rare for Black women to do because both the Harmonica and Drums had been, 
and to some extent still are, associated with masculinity. Robey saw Big Mama perform at the El Dorado Ballroom in Houston Texas (Gaar; 5).

Robey signed Thorton to a five-year contract with his Peacock Records Label shortly after their meeting at El Dorado (O'dair, 1997). This independent studio was later called Duke-Peacock which would subsequently be lauded for producing the best of the gritty R\&B and gospel records Houston had to offer(1997). This record label was an important influence on soul music and rock and featured artists such as Marie Adams, Johnny Ace, and a young Little Richard and more(1997).

Big Mama Thorton was a huge asset. She was even thought to be "almost too perfect” of a fit. Robey had one major gripe about her. Big Mama Thorton was very openly a lesbian (O'dair, 1997). Not only was Robey uncomfortable with her sexual orientation, but he was also openly and incredibly uncomfortable with Big Mama’s gender performance, even though Robey was often described as a "flamboyant” black entrepreneur, which I take to mean that he performed in a way that was considered to be queer for his time and social millieu (Gaar, 1992; 4). Robey quipped that it was hard to find queer clubs or safe spaces for Big Mama to perform, even though he still managed to book shows for her. According to the recently updated Smithsonian archival records of Big Mama and Robey's work relationship:

“Thornton's open lesbianism caused some tension with Robey, but he produced her first recordings and set up a regular performance schedule for her in his Houston club, The Bronze Peacock, and on the southern performance trail known as the "Chitlin' Circuit." This string of clubs and venues covered the eastern and southern United States and were considered safe for African American musicians 
to play in. They ranged from the Cotton Club in New York's Harlem neighborhood to local juke joints in Mississippi. Thornton spent much of the early 1950s on the road or recording for Robey or Johnny Otis when in Houston or Los Angeles" (2019).

Big Mama spent a lot of time travelling to Los Angeles, California back to Houston, Texas(Gaar, 1992;5) .Big Mama eventually moved to New York City with the Otis Show, her band, to play at the Apollo Theatre in 1952 (5). Initially, she was slated as a performer to open for R\&B artists "Little" Esther Phillips and Mel Walker but soon was promoted to the headlining act(5). Later that year, Big Mama moved to southwest Los Angeles(5).

During a recording session, Big Mama was approached by the young songwriting duo, Jerry Leiber and Mike Stoller-- who would eventually become Rock and Roll songwriting legends. Stoller and Leiber were fascinated by her curvy-body and the robust growl of her singing voice. The duo wrote Hound Dog, a 12-bar song just for her. Big Mama embellished the song with blatant sexual references, whoops, and barks, and other animalistic elements.

Thorton's Hound Dog was released nationwide in 1953 and soon topped the R\&B charts (Gaar, 1992;4). Despite its sale of two million copies, Thornton received only \$500 (Smothsonian, 2019;5). Big Mama Thorton faded into obscurity after Elvis released his version of Hound Dog.

In the late 1960s, she made several seminal recordings for Chris Strachwitz, producer of Arhoolie Records. These seminal records would include: Big Mama 
Thornton: In Europe which was backed by Buddy Guy, Walter Horton, and Freddy Below in 1966 (Gaar, 1992;10). She also released a record entitled Big Mama Thornton with the Chicago Blues Band with Muddy Waters, Sam "Lightnin'" Hopkins, and Otis Spann in 1966. One of the known records she recorded was Ball \& Chain in 1968 which was an original compilation by Thornton, Hopkins, and Larry Williams (Gaar;10).

Even though Big Mama was fading into obscurity, Rock musicians in the 60's took notice of her work. The title song Ball \& Chain became a signature song for Thornton's great admirers (Spörke, 1992; 11). Janis Joplin covered Ball and Chain with the same spirit of intentional minstrelsy as Elvis Presley did. Joplin, just like Presley, became well known for their versions of Big Mama’s song (Spörke; 12).

Not much else is known of Thorton. However, Big Mama Thorton died of complications due to a heart attack in Los Angeles on July 25, 1984 (Smithsonian, 2019; 6). She was only 57 years old (6).

\section{Big Mama Thorton and Black Feminist Thought}

Big Mama Thorton's life story and musical career path follows the patterns of the Black Femmes who preceded her and those who followed in her footsteps, to varying degrees. From her humble beginnings with her brother, to her singing in church, to the death of her mother, which led to poverty with her family, to her rise to stardom, and to her fall from the spotlight--she directly embodies Black feminism in action. 
There is evidence that situates her Black Femme and rebellious life story and performance to a larger rhetoric that surronds Black femmehood. Her most lauded and commercially sucessful work, Hound Dog, provides a text-based account of her connection to the rhetorics of Black Feminist Thought. I deconstruct the lyrics to Hound Dog to demonstrate this connection and use it as another instance that situates Thorton within Rock and Rock history as well as posits her within Black Feminist music and discourse, as it speifically relates to the sexual and class-specific ethics that are found within Black communities as these relate to the dynamics between Black men and women that are demonstrated in the creative connections and major trends in Black Feminist Thought. I insert commentary as the lyrics progress. These are the lyrics to the chorus and first verse of Hound Dog:

Chorus 1:

You ain't nothing but a hound dog

Been snoopin' 'round the door

You ain't nothing but a hound dog

Been snoopin' 'round my door

You can wag your tail

But I ain't gonna feed you no more 
Verse 1:

You told me you was high-class

But I could see through that

Yes, you told me you was high-class

But I could see through that

And daddy, I know

You ain't no real cool cat

The first verse and chorus sets up the characters in this story-song. What I find most intriguing about how Thorton is telling this story of her no good lover is that she assumes the position of authority. She admits that she willing overlooked by this "hound dog's", which in African American Vernacular of the time simply meant a "a man who used women for sex and money and had particularly dishonest or lazy tendencies", she lie because while she wanted to have sex and perphaps the comfort of another person, her lover has overstayed his welcome and she can no longer tolerate his company anymore.

Thorton's lyrics point to pro-sex attitudes and her general sense of sexual autonomy. This is quite consistent with who she was as an openly promiscuous lesbian women, although I assume her sexuality was concealled to to general public in order to sell records as the characters in this song are alluded to be in some sort of heteronormative sexual relationship. Her pro-sex attitude is also timely as Thorton's hit is released in the foregeound years before the Civil Rights Movement of the 60's, which 
was simultanosely a time when many Black women, Black queers and Black LGBTQ+ individuals were advocating for sexual and gender equality.

\section{Chorus 2:}

You ain't nothing but a hound dog

Been snoopin' 'round the door

You're just an old hound dog

Been snoopin' 'round my door

You can wag your tail

But I ain't gonna feed you no more, oh play it on Sam, oh!

Verse 2:

Aw, listen to that there old hound dog

Oh, play it, it s'all right in here

Oh, listen to that there old hound dog holler

Oh, play it boy, play it

Oh, you make me feel good

Oh, do the mess around right now, yeah

Now wag your tail

Oh, get it now

Oh, get it now, get it, get it, get it 
Oh, go, holler boy

The second verse, coupled with the chorus, adds some class commentary to the story. Thorton is still giving credit to this Hound Dog's sexual prowess and hints at their mutual enjoyment of their sexual escapades with her liberal use of "holler". However, she belittles his ability to contribute financially to her household by prompting him to find financial stability in "Sam", or rather "Uncle Sam". This follows the historical pattern of Black women being able to be the primary income earners in their households, even though she and many others still lived in near or in abject poverty.

I think it is reasonable to argue that all characters in Thorton's story-song are either living in poverty or near poverty as Thorton asserts through her lyrics that the man in question's status was not only poor but her use of the terminology "hound dog" also contends that the lover in question was also a user. However, we do not have explicit indicators of Thorton's class status. Thorton's diction is the only indication, coupled with her biographical information, of her class status. She uses fairly deep African American Vernacular English which is generally and unfairly associated with a particular class strata in the 1950's which is the result of efforts to educate, and ultimately white wash, more affluent Black individuals.

Bridge:

You made me feel so blue

You made me weep and moan

You made me feel so blue 
Well you made me weep and moan

'Cause you ain't looking for a woman

All you lookin' is for a home.

Verse 3:

You ain't nothing but a hound dog

Quit snoopin' 'round the door

You ain't nothing but a hound dog

Quit snoopin' 'round my door

You can wag your tail

But I ain't gonna feed you no more, oh (Leiber, Stoller; 1953)

Thorton was, in her own way, reflecting a history of Black Feminist anti-sexist rhetoric by reclaiming her space and voice by calling out misygnoir or otherwise heterosexist behavior. Through her use of playful metaphor, Thorton was conveying discontent with the status quo and made a mockery of the sexual politics of the time.

This sentiment is also found in Angela Davis work Blues legacies and Black Feminism: Gertrude "Ma" Rainey, Bessie Smith, and Billie Holiday. Davis argues that the Blues genre is not just a musical tradition, but that it was also a life-sustaining vehicle for an alternative black and working-class collective memory. It reflects a sort of social consciousness that is significantly in opposition with mainstream American middle-class values. 
Although Davis speaks specifically about Gertrude "Ma" Rainey, Bessie Smith, and Billie Holiday, Davis still offers that the Blues for Black women and for Black femmes embodied an artistic triumph and also an aesthetic dominance over a hostile popular music industry. She also contends that the contributions of Black Femmes have been largely ignored. Davis finds evidence of proto-feminist consciousness within working-class black communities that exposes the distinct pattern of celebration of working class, poor, queer and gender non-conforming attitudes that demonstrate liberal sexual ethics and pro-sex attitudes.

Although Davis focuses on blues musicians, I find it interesting to note that Rainey and Bessie Smith were good friends with Thorton. They were known to socialize at bars with one another on multiple occasions, as they shared social milieus. There is a certain sort of co-mingling and sound sharing between their genres of music and the music-makers that create them.

Black femmes music-makers in North America have used music, among other means, to reclaim their identities and used it as a way to legitimize their voices as powerful, resilient, and beautiful. Just as Big Mama Thorton, many Black femmes began their musical training in the Black church and in the home with their close relatives. They often used their music to rebel against religious and otherwise patriarchal standards placed upon them while financially providing for their families . In the process, Black femme creators, like Big Mama, became innovators and genre-bending, powerhouse musicians. 


\section{CHAPTER 2}

\section{TRANSNATIONAL BLACK FEMINIST INDENTIES IN MUSIC: EXPLORING THE SHARED IDENTITIES BETWEEN BLAKC NORTHAMERICAN AND AFRO ARGENTINE FEMMES}

Music is one of the most powerful tools of resistance that Black femmes have used to fight systemic oppression throughout the African Diaspora. Music reveals many shared oppressions, ideas of community, intersecting identities, and ancestral closeness between Diasporic peoples, even though they are continents apart. The shared experiences of African American and Afro-Argentine Femmes participating in underground music renders a concept of Black Femme existence that is phenomenologically and aesthetically comparable. Afro-Argentine and African American musicians use music as a shared platform as well as a form of uniquely Black expression. I specifically focus on underground rock music as one which is an instance and example of a shared Diasporic musical artform, even though I will also touch on other forms that are very much intertwined.

I introduce the Black femme music makers of Afro Argentina by giving a history of Afro Argentina, musical developments that specifically arose from spiritual expression, enslavement, and resistance to colonial powers. I use oral histories I performed with living Afro Argentine music-makers and community activists to uncover a small portion of a grander social history of Afro Argentine music. I also use these oral histories to serve an anchor point for concepts concerning race, class, and gender as understood by Afro Argentines. I then explore the links between the history of gender, 
race, and class in order to uniquley tether Afro Argentine experiences to Black North American Feminist Thought as I explored it previously.

\section{Afro Argentina: History and Culture}

Argentina is regarded as the 'most white' country in South America. According to the 2010 Argentinian Census, it is estimated that the present-day total population of Argentines is approximately 42.3 million people with African Ancestry being around 149,493 people country wide (Republíca Argentina, 2010). However, the Afro descendent population that resides in Argentina are the last of a once populous people group, as Afro Descendants comprised approximately 2/3 of the population in the early $19^{\text {th }}$ century( Reid, 2004; 16) .

African peoples did not come to Argentina by accident—nor by their own volition. Enslaved Africans first arrived in Buenos Aires, Argentina from present day Brazil in 1584 (Reid, 2004; 16). Enslaved Africans constituted 70 percent of the commercial goods sold, traded, and exported throughout the region, with trade roots extending as far as present day Bolivia, Chile, Paraguay, and Southern Peru (Reid; 17). Many enslaved Africans were transported to Córdoba, Argentina for redistribution to the rest of the country, aside from Buenos Aires which was the point of entry for enslaved peoples taken primarily from Angola, Namibia, and other Western African States until around 1610 (17).

Enslaved peoples were extorted in numerous ways, often finding themselves being used as tools in the religious agenda as well as utilized as socio-political and 
economic assets. In 1610, the Society of Jesus established the Coliseum Maximum for the Jesuit order in Córdoba which the enslaved peoples built and maintained (Oxford Biographies, 2019). Towards the end of the $17^{\text {th }}$ century, the enslaved population exponentially increased, so much so that they constituted around one-third of the total Argentinian population. They were brought to Argentina in order to maintain churches, schools, universities, ranches, and military efforts. Towards the end of the $18^{\text {th }}$ century, the Río de la Plata Basin became a strong economic force within South America, with Buenos Aires as the most benefited from the enslaved presence in the region (2019). The Río de la Plata Basin became a confederation shortly after. The enslaved African population increased exponentially as Argentina grew more economically stable.

The enslaved population contributed significantly to the labor force as well as being considered liquid assets. During the $18^{\text {th }}$ century, a period when African peoples were still enslaved, there was a burst of religious music that blended traditional catholic melodies with the sounds of African chants and instruments—a musical development that is linked to afro-argentine women who were priestesses and servants to in city centers like Buenos Aires (Karush, 2012; 217). There was an abundance of payadas created, which are call-and-response style sung poetry, by gauchos in the field of rural Argentina as well as in Buenos Aires (217). Which indicates that African presence and influence was ever present in popular culture in the 1700's. These payadas were created, in part, to alleviate the suffering under colonial powers and served as a coded form of communication with other enslaved individuals.

Argentina began to experience political unrest in the mid $19^{\text {th }}$ century. Buenos Aires began to fight for their independence from Spain in 1810. The rest of the country 
shortly followed suit. Buenos Aires’ militia consisted mostly of local fighters and relied heavily on enslaved populations to fight. The Argentine War of Independence was fought from 1810 to 1818 by Argentine patriotic forces under Manuel Belgrano, Juan José Castelli and José de San Martín against royalist forces loyal to the Spanish crown (Reid, $2004 ; 16)$.

Argentina declared independence from the Spanish Crown in 1816, although the process to official independence started a few years prior (Reid, 2004; 17). Slavery in Argentina gradually abated beginning in 1813 with the Free Womb Act, which "freed" all infants who were born to enslaved women (Reid, 2004; 18-19). In 1853, The first Constitution of Argentina abolished slavery (19). Every state that was part of the confederation followed suit. Bolivia, Peru, Paraguay, and Chile abolished slavery within their borders.

Most of Argentine abolished slavery as well— except for Buenos Aires. This is because Buenos Aires is and always has been an autonomous city which operates within Argentina. This means that the city has been able to operate very much like a commonwealth state in the United States of America. Buenos Aires was granted permission to create their own government, laws, and ordinances (Reid, 2004; 21). As a result, Buenos Aires did not abolish slavery in its province until much later because Buenos Aires was not part of the Confederation that advocated for the abolition of slavery, as it operated as an exclave from the greater Argentina (22). The slave trade was too profitable in Buenos Aires and comprised the majority of the ecomonic capital. In 1861, Buenos Aires joined the Confederation and "abolished' slavery. 
Even though the enslaved were free, Afro Argentine were not welcome in Argentina. The Argentinian government began its blanqueamiento ,"the whitening”, of the country. Whitening efforts were characterized by political and governing bodies efforts to erase African Argentinians from the history of the country, its people, and its culture—although individuals of Indigenous South American descent were subject to whitening efforts to a significantly lesser degree.

Argentinian Blacquemiento happened in similar form to other whitening efforts across Hispano-America. In Anne McClintock's work 'No Longer in a Future Heaven': Gender, Race, and Nationalism, a work in which she centers the Afro Cuban experience of whitening, McClintock makes a claim that is true of most whitening efforts in central and south American. She argues that all nationalisms are gendered and arguably an effort towards white supremacy $(1997 ; 9)$. She goes on to argue that not only are the needs of the nation typically identified with and tied to the frustrations and aspirations of men, but the representation of male 'national' power depends on the prior construction of "gender differences" (Ibid).

The mechanisms that facilitate the invention of specific national discourses, and the ways in which these nationalisms are performed, vary depending on the localized histories of different national and political contexts (McClintock, 1997; 10). This was most certainly the case for Afro-Argentine women, who were coerced to interracially procreate in order to purify their children's blood and rid them of their "Punto Negro" (Ibid). Afro-Argentine men were used as military pawns, or "disappeared". Miscegenation was at an all-time high. 
Cultural products created by Afro-Argentines were subsequently devalued, coopted, appropriated, or erased from mainstream Argentine culture. Practitioners of the sacred music of the Candombe, whose name literally translates to "dance in the honor of the gods (gender neutral)", retreated to the mountains of Argentina and Montevideo, Uruguay with the women who dance to the Candombe (Friegerio, 2002; 291). The gauchos preserved the payada tradition in the fields of the Black Farmlands of Patagonia. Tango was taken from the remaining formerly enslaved African peoples in Buenos Aires and was stripped of its African soul, rendering what is now ballroom standardized Tango.

There have been some academic efforts to recover the history lost during blanqueamiento. This comes with great struggle as noted by Marvin Lewis in his work Afro-Argentine Discourse: Another Dimension of the Black Diaspora. Within this work Lewis attempts to reconstruct an Afro-Argentine discourse that creates a post-colonial understanding of Afro-Argentine discourse which works within the constraints of AfroArgentine romanticism and criollista history while maintaining the irony and parody that is used express the Black (I) as a subject (Lewis,10).He warns that a strictly romantic/creole understanding of Afro-Argentine work reinforces hegemonic theories that dominate both Hispano-centric and Afrocentric post-colonial studies of cultural products without answering what black is in Argentina (11). There must not only be a link between both Afrocentric and Eurocentric in order to understand Afro-Argentine identity as it is expressed as a cultural product and reaction to and a hybrid of both.

From the moment that African people arrived on Argentine soil, they have approximated a concept of negritud, a concept that is most commonly connected to Léopold Sédar Senghor. Argentine notions of negritud formed more cohesively in the 
nineteenth century and explored in payadas. In a more current discussion of Afro Argentine negritud, Julio Fin states:

Négritude has been inextricably involved in a long, it gives no quarter war with colonialism and racism. And it is this which makes Négritude unique: it is the only artistic movement of modern times whose expressed creed is to redeem the spiritual and cultural values of a people. Born in the red-hot crucible of colonialism its political stance is important to it as its artistic one. On the cultural level, Négritude vaunts the inimitability of the Black Civilization; on the human level, it proclaims the innate dignity and beauty of their race- - the right of black peoples proudly to cast their shadows in the sunlight (Fin, 21).

Perhaps one of the most basic arguments against negritude theory is that negritude ultimately relies on its structure that is derivative and replicatory, asserting not its difference, as it would claim, but rather its repentance in categories of race and features of colonizing ideas (Lewis, 1995; 34).

This critique rings particularly true to Afro Argentine payadores who present one of the first sung challenges to Negritude in Songs of Africa, published in 1877. This payada is possibly one of the most well-known Afro Argentine poems that lyrically poeticizes the social concerns of the Afro Argentian peoples during the transition from slavery to freedom. Contained within the poem are key concepts of Afro Argentine blackness: dualistic existence, liberation, confrontation, and identity born of the confusion of love, pain, irony, and paradox.

The tone of this poem is quite hostile, as to be expected. Song of Africa was originally published in parts in a newspaper called La Juventude (Lewis, 1995: 81). 
However, Jorge Miguel Ford publish the full, definitive version of this poem in Outstanding Member of My Race. ${ }^{\text {xix }}$ Ford's version of the poem is the version I provide below:

Bajo un cielo fulgente

De límpido color, con blancas nubes

Como tejidas alas de querubes,

Cielo con millones de luceros

Que refulgen en noche de embeleso

Con amante porfia

Cariciando la tierra con su beso

Bajo un sol de flamigeros colores

Que ilumina el espacio en rayos de oro:

Con aire de aromas y un tesoro

En rubíes y perlas de sus flores;

Hay una tierra virgen que fue cuna

Por duelo o por fortuna

De una raza que es mártir por su historia,

Raza digna de gloria

Porque es noble y altiva

Como el león que entre la selva mora.

Y que en acerba hora

Arrastróla al abismo de la infamia.

¡Ah! Sin temblar la fraticada mano 
De un bárbaro Caín, cruel, inhumano...

(Under the bright sky,

Of clear color, with white clouds

With woven wings of cherubs

A sky with one million stars

That take refuge in a night of fascination

With lover's persistence

Caressing the earth with its kiss.

Underneath a sun of flaming colors

Which illuminates space with golden rays:

With an air of scents and a treasury

In rubies and pearls of its flowers:

There is a virgin land that was birthplace

For pain or for fortune

Of a race which is martyr through its history,

A race of glory

Because it is noble and proud

Like the line who enters the jungle dwelling.

And who in the bitter hour

Dragged it to the abyss of infamy.

Ah! Without trembling the fratricidal hand

Of a barbarous, cruel, inhumane Cain...) 
This is but a taste of the full poem. Immediately, the poem is distinct. Aside from the tone, Songs of Africa is written in a very rhetorical and distinctly African writing style—very much like the rhetorical mode of African literature that Edward Kamau Brathwaite conceptualized. In this rhetorical tradition, writers use Africa as a general mask, and as a signal of nomen (Lewis, 1995, 82). The payador doesn't know much of Africa necessarily, but uses Africa to invoke a deep desire and connection, without invoking the name. Songs of Africa creates a metaphorical world where there is some sense of harmony between the people and their land in a romantic way. The idea of being a martyr and oppressed are curiously paired with the image of destructive and biblical forces.

Much more can be said about Songs of Africa, and of general Afro Argentine discourse. However, I find that there is a distinct lack of Afro-Argentinian Femme thought written into the Argentinian discourse. This is quite troubling. Afro Argentine women have participated in tremendous ways in the development of Afro Argentine culture. In continuation of the groundwork laid by Songs of Africa, Afro Argentine women used the art of payada to share their Black experiences enriched by their Femme experiences.

\section{Afro Argentina: Religion, Gender, and Myth}

Gender in Afro Argentina is far more nuanced and fluid than Western sensibilities are accustomed too, or expect, in a country where strict gender roles and social norms are assumed to be fixed and binary. Afro Argentines assimilated into a strict binary-oriented gender role as a result of Whitening and Christianizing efforts 
(Lewis, 1996; 5). However, Afro Argentines preserved their gender fluidity within their cultural products, particularly in music and theatre spaces. In these spaces men and women shared equal space and were often encouraged to support one another to create cultural works.

Gender equality and fluidity was commonplace in Afro Argentine communities until the early 1910's when Argentine women of European descent began organizing under the guise of feminism (Blanksten, Carlston, Little, 1990; 663). In one of the oral histories I gathered during my time in Buenos Aires, I spoke with an 89-year-old woman named María who corroborated this account. She stated:

"Ceila, no. No hubo separación de mujeres y hombres. No podríamos estar separados. Éramos muy pocos de nosotros Los hombres conocen nuestra historia al igual que las mujeres conocen la historia de los hombres porque no hay diferencia. Ustedes, aquí, hablan sobre nosotros porque [las mujeres] no les hemos dicho a ellos 'icállate! Todavía. Nuestros hombres hablan por nosotros porque les dejamos hablar. Los hombres y las mujeres tienen diferentes roles en la vida, pero están unidos. Los hombres cuidan la tierra y las mujeres cuidan el espíritu y la tierra (Jones, 2018).

[No, Sweetheart. There was no separation of women and men. We could not be separated. There were very few of us. Men know our history just as women know the history of men because there is no difference. You, here, talk about us because [the women] have not told them 'shut up!' still. Our men speak for us because we 
let them speak. Men and women have different roles in life, but they are united. Men take care of the earth and women take care of the spirit and the earth (Jones, 2018)].

After a bit of clarification during our conversation, María expressed that she was specifically referring to the Candombe ceremony and religious tradition, which is dance and music oriented. Men were responsible for keeping the grounds, men and women both participated in writing the ceremonial music, but women were the "mothers of the holy one” (Jones, 2018). This meant that women facilitated the ceremony, musical cyphers, and were the primary participants in the song-dance for god, leading future priestessespractitioners in the way of the tradition.

Candombe features a set of liturgical movements that are choreographed top hymns. This dance is a call to the spirit world, very much like the dances found in Vodun (Cirío, 2015:116) . The dancer(s) catch the spirit of their orisha (Ibid). After catching the spirit, the practitioner then enters into a trance and dances alone under the watchful eye of the "mothers of the holy one" (Ibid). The gods are then expelled from the space and then the entire ceremony is performed in reverse order. Producing and sustaining spirit is essential to Candombe ceremonies.

African dancing was well known to the enslavers of South America. Like many other African Diasporic communities, dancing was an integral part of the music making process as movements often produced percussive sounds adding to the polyrhythmic and participatory nature of Black music alongside shouting, yipping and other vocalizations (Cirío, 2015; 116-117). Even though liturgical dancing was forbidden by The Church, the enslaved Afro Argentines would still dance and drum in the fields during periods of time 
when they were not working. Music performance became important symbols of rebellion as "their rhythmic movements and rocking bodies belied the truth behind the dances" (Cirío, 2015; 118).

\section{Radical Black Femmes In Aregentina's Popular Music}

Black Argentines have a long history of using Music as a tool of radical protest. Afro Argentine women have been instrumental to successful political mass demonstrations that protested the Argentinian government by using music performance. One of the most notable of these feminist figures is Mercedes "La Negra” and “Godmother of Argentinian Folk Music” Sosa (Foster, Thompskin, 2001; 318). Sosa was born in Tucumán, Argentina in 1935 (Ibid). She began performing music at 15 years old with her song "I’m Sad" which catapulted her into her music career (Ibid). Sosa was known as "the voice of the silent majority" (319). Sosa was given the epithet because of her overtly political lyrical material. With the help of fellow musicians of Indigenous Argentinian descent, Violeta Parra and Atahualpa Yupanqui, Sosa championed the rise of Nueva Cancionero movement in the 1960's, which is colloquially referred to as the "Argentinian Black Artist Movement" (320). Nueva Cancionero was an expressly musical and political and the Afro and Indeginous Argentine feminist movement was intentionally created as a means of protest against the Argentine government.

In 1973, the movement was crippled by a CIA-sponsored coup (Foster, Thompskins, 2001; 319). This is the same US-backed coup that ousted President Salvador Allende within that same year (Ibid). Mercedes Sosa was considered a serious 
threat to Argentine national security and, was in effect, considered a domestic terrorist. Sosa and her supporters were heavily monitored and their shows were often disrupted by police (Ibid).

In 1975, Sosa and some audience members were arrested during a live performance (Foster, Thompskins, 2001; 233). Sosa was one of the estimated 30,000 attendees who were forced into disappearance by the Argentinian military who were serving the National Reorganization Process Regime (Ibid). Sosa was later "found" and then incarcerated for approximately 4 years (234) . In 1979, she was released but was forced to flee Argentina due to death threats. She remained in exile for approximately three years (Ibid). After Sosa's exile, there was a marked decline of Black Argentine music in popular culture.

The late Sosa centered the Black experience and championed the well-being of her people. This is evident in her lyrics to Duerme, Negrito which is a lullaby that also takes the form of a Payada. This is a lullaby whose origins are a bit ambiguously located by the Colombian and Venezuelan border. Sosa popularized this lullaby among Argentines with her rendition of this folk tune. I used a rough translation, which is located below. It should be noted that there are lyrics that I have not translated because they are in indigenous tongues of which I am not fluent nor familiar. The lyrics are as follows:

Duerme, duerme negrito

Que tu mama esta en el campo

Negrito

Duerme, duerme negrito 
Que tu mama esta en el campo

Negrito

Te va a traer codornices para ti

Te va a traer muchas cosas para ti

Te va a traer carne de cerdo para ti

Te va a traer muchas cosas para ti

Y si negro no se duerme

Viene diablo blanco

Y sale comen la patita

Yakapumba Yakapumba

Apumba Yakapumba Yakapumba Yakapumba

Duerme, duerme negrito

Que tu mama esta en el campo

Negrito

Duerme duerme negrito

Que tu mama esta en el campo

Negrito

Trabajando

Trabajando duramente

Trabajando, si 
Trabajando y no le pagan

Trabajando, si

Trabajando y va cosiendo

Trabajando, si

Trabajando y va de luto

Trabajando, si

Pal negrito chiquitito

Trabajando, si

Pal negrito chiquitito

Trabajando, si

No le pagan, si

Duramente, si

Va cosiendo, si

Va de luto, si

Duerme duerme negrito

Que tu mama esta en el campo

Negrito

Duerme duerme negrito

Que tu mama esta en el campo

Negrito 
(Sleep, sleep black

That your mom is in the field

Little Black One

Little Black One

Sleep, sleep black one.

That your mom is in the field

Little Black One

Little Black One

It will bring you quail for you

It will bring you many things for you

It's going to bring you pork for you

It will bring you many things for you

And if black does not sleep

White devil comes

And it comes out eat the little leg

Yakapumba Yakapumba

Yakapumba Yakapumba 
Apumba Yakapumba Yakapumba Yakapumba

Apumba Yakapumba Yakapumba Yakapumba

Sleep, sleep black

That your mom is in the field

Little Black One,

Little Black One,

Sleep sleep Little Black one

That your mom is in the field

Little Black One,

Little Black One,

Working

Working hard

Working, yes

Working and not paid

Working, yes

Working and sewing

Working, yes 
Working and going mourning

Working, yes

Little Black Boy Pal

Working, yes

Little Black Boy Pal

Working, yes

They do not pay him, if

Hardly, if

It's sewing, yes

It goes in mourning, yes

Sleep sleeps, Little Black One

That your mom is in the field

Little Black One,

Little Black One,

Sleep sleeps, Little Black One

That your mom is in the field

Little Black one,

Little Black (Sosa, 1973). 
Duerme Negrito is considered radical for a few reasons. First, It is a clear reference to enslavement. Argentina has been resistant to acknowledging their genocidal past, until recently. Second, Duermo Negrito is clearly feminst as it references the role of women within the context of enslavement and childrearing. Lastly, the song features Santiagueño Quechua which was an indigenous language spoken in the province of Santiago del Estero, as a form of linguistic resistance and reclamation of their Indigenous roots (Foster, Thompksins, 2001, 335).

Although I have highlighted Mercedes Sosa, her story is not unique. Argentina's mainstream culture has consistently positioned itself as antagonistic to Afro Argentines and the cultural products they create. Many works have been appropriated by Argentinian Culture at large and Afro Argentine contributions have historically been washed away.

There is a revival of Afro Argentine Music in popular Argentinian culture. African diasporic musical traditions that were lost or reclaiming indigenousness languages or dialects such as Argentinian Quechua and Africano have been resurfacing in fragments.

Although there is a new found expressed interest in Afro Argentine music and culture, there is still a distinct lack of Afro Argentine women actively working in popular media since the late 1970 's. This is partly due to the lack of large Afro Argentine populations. The lack of Afro Argentine popular music is also partly due to Argentina's particularly hostile and anti-Black history.

Black Argentinian music survives underground. Afro Argentinian communities continue to enjoy music, arts, and culture in spaces that they have repurposed. These 
communities stretch From Buenos Aires all the way down to Patagonia Area. Espacio Malcom, located in Villa Crespo in Buenos Aires, is one of the most high-profile and radical Black and feminist spaces that facilitates cultural production. It is part radical library space, meeting space, and educational space. That serves as a venue for musical performances, and Barbershop that is an extension of the Diaspora Africana de la Argentina nonprofit. This space is grassroots and sustained by the participation of Afro Argentine men and women alike under the direction of Frederico Pita, an Afro Argentine of Jewish heritage. Efforts like this can be found across the River Plate Basin. Many Afro Argentines are creating spaces solely for Black Argentine cultural production as an act of reclaiming space and an active step towards raising community consciousness.

\section{Blackness in Music: Spirit of Rebellion and Resistance}

The spirit of rebellion and the spirit of Blackness are one and the same. In a fortunate and quite serendipitous occasion, I met with a woman who chose the pseudonym Isabel. I happened to run into them while walking around the School of Music in Buenos Aires. She is studying jazz percussion at the School of Music and is a drummer in a local punk group called Los Animales.

I asked her if I could do an oral history with her, as she is an young Afro Argentine femme who is active in the local punk scene, and I just so happened to have my recording gear with me. Isabel agreed. We walked to a practice room within the school and closed the door. I pressed play. Before I could get a word out my mouth, Isabel began to quiz me. It was as if I was the one being interviewed. Isabel asks, "What 
led you here, to us, when you could have chosen any other place in the world to study black people in music? Do you know there are very little of us [black people] here?” Without giving a pause for me to answer she responded, "the spirit told you to come" (Jones, 2018).

I was dumbfounded and unsure of if I was supposed to be offended. After a bit of a pause, Isabel began to tell me her journey as a musician. She told me that she started playing music at the encouragement of her family. She grew older and she began branching out to learn how to play different genres of music. She said that she really liked playing all forms of music that moved the spirit—-that is what music is supposed to do. She recalled a time when she played as a filling drummer for a rock band for a punk show and was amazed at the crowd as they moshed. She says to me "I have never seen so many Porteños move to punch so many people" (Jones, 2018). She proceeds to tell me that she cannot explain why she plays music or how her blackness is expressed through it, because it is truly just a feeling. She just feels moved as she claims "her soul feels alive" (Jones, 2018).

What I found most interesting was the way that Isabel connected spirit, music, and blackness together. And at the end of our oral history, I found myself amused by my own equivocation between the spirit of a mosh pit and catching the spirit during church and proceeded to ramble for a long time about the similarities between a mosh pit and catching the holy ghost. Isabel smiled and nodded along as I continued to jabber on, as she thinks there is a spiritual connection between music and the human spirit and the divine. 
Isabel proceeded to tell me about one of her idols, Mercedes Sosa, who was also known to hold drumming circles in the early 1970's. She told me all she knew about indiginous drumming patterns. And she briefly touched on the influence of traditional African Drumming on Argentinian Jazz in the mid 1920's. She briefly recounted the story of the Nuevo Cancioneros movement and talked about how this movement centered Black liberation, Afro Argentine family, and the experiences of Black peoples in their communities. Black Femme's labor and creativity are at the heart of these traditions. Nuevo Concieneros often played Folk music, Blues and, Rock-style music. She also told me that she hopes that this movement returns.

\section{AfroLatinidad}

I struggled to receive a clear answer on how Blackness andFemme-ness inform musical performances from the orators I met with. This is in part due the limitations of how Black North American defined Blackness. However, none of my orators hesitated to claim their African heritage. Although they did not strictly define how they understand their Afro Argentine-ness, they never once neglected to clarify to me that they are Afro Latinas - they exist wholly as a one person of two complete parts. They are all African and all Argentine. In fact, during my oration with Isabel, she asked me, “¿Dónde encuentro mi sitio con "Blackness” cuando tengo dos partes diferentes a las tuyas? -¡Hermana, dime!

[Where is my place in "Blackness" when I am [ I have] two parts that are different from yours? Sister, Tell me!”. ] 
She called my attention to a big problem of locatability within concepts of Negritude and Latinidad both of which give primacy to western and northern hemispheric people in relation to specific parts of Africa that have historically fallen under British, Dutch, Belgian or German powers. Many Afro Argentines, including Isabel, feel as though they have been ignored from conversations around Afro Latinidad because Argentina is assumed to have an insignificant population of African descent andbecause they have been excluded from the conversation around Afrolatinidad, the Afro Argentine femme experience does not readily situate within the concept of Latinidad.

Afrolatinidad is being explored by feminist researchers throughout the diasporamost notably in the United States and the Caribbean. It is a more useful concept to utilize when attempting to grasp the complexities of Afrolatinadad. While feminist researchers acknowledge the limitation of their scholarship, many argue that the concept of Afrolatinadad extends to across the Americas. Afro Latinidad is admittedly, and arguably necessarily, a broad term that typically signifies a subject that is Latin American and of African descent—although there is very rigorous and necessary debate on what exactly "Latin descent" means. This term is given to the projects that identify a hemispheric political and racial identity that is located by the emerging social movements of Black Latinos ( Laos-Montes, 2005;117).

Afro Latinidad is a concept that calls for plurality that is still substantive enough that discursive analysis can still be done and meaningful as well as call attention to the specific location of local communities within both the African and Latiné Diaspora globally. Mapping Afrolatinidad requires an analysis of the history of the community as well as the relationship that the community has with their African-ness, Latinidad, and 
their American-ness. This produces a tripartite framework in which current definitions of Afro Latin identity can be situated. There is an implied unidirectionality to this argument, which starts with most imperialized identities such as North American Black and North American Latino that tricks down to the global South (Loas-Montes, 2005; 18).

The concept of Afro Latinidad runs the risk of being essentialist, patriarchal, western-dominated, and falling victim to the discursive power of post-colonial studies as it is currently practiced. Petra Rivera-Rideau, Jennifer A Jones, and Tianna Paschel offer a potential solution to this issue by providing a new perspective to situate Afro Latinidad. In their preface, the researchers state:

While literature on (Afro-) Latinos and (Afro-) Latin Americans have largely been conceptualized as distinct, some scholars have addressed the ways in which conceptions on race flow across borders....[These] "latinities" attend to the fluidities and contestation to US Latino identities in part to emphasize their connection to Blackness. [...] However, rather than assume unidirectionality of these flows, we demonstrate that movement of ideas of Blackness are multivalent, continuous, and ever changing (2016;12).

Afro Latinas actively fight against scholar's tendency to conflate Afrolatinx identities within the broader category of "Black", mostly because it assimilates them into an identity that does not precisely match their own. Angela Jorge makes note of this in her work The Black Puerto Rican Woman in Contemporary American. While her project focuses on the Afro Puerto Rican experience, she makes a larger claim about the large Afro Latinx community. For brevity, I summarize Jorge's main claim which is: [what is] 
at stake in this erasure is the "genocide" of Black Puerto Rican women who may "assimilate” into African American communities, and thus no longer be connected socially and emotionally with her community $(2010 ; 182)$.

For Afro Latiné individuals throughout the African Diaspora in the Global North and South America, many are forced into choosing either the Blackness of themselves or the Latiné part of themselves resulting in their misidentification or disidentification with either or all of themselves. Those who identify with both aspects of their identity experience a sort a double-consciousness that is akin to the Black North American experience except with the unique feature of hybridity, as both Black and Latiné identities are couched in a larger discourse of whiteness and belongingness that Afro Latinés, especially those in Afro Argentina, cannot fully access. Afro Argentines are in a unique position as much of their identity is a reaction to Black North American ideas of Afro Latinidad.

Afro Latinx people do recognize that they face an equivocal form of antiBlackness as Black North Americans—despite their identities being distinct enough not to be collapsible. In the article Expanding the Dialogue: Afro Latina Feminism, researchers interrogate Afro-Latinindad as it relates to an inclusive Black Feminisms. Petra Rivera-Rideau, Omaris Z. Zamora, Sandy Plácido and Dixa Ramirez assert that issues of Afro Puerto Rican women Black women have a long and deeply rooted heritage in Latin America and are reflective of the Black American Latiné experience as a whole( 2017;1). These AfroLatiné women assert that Afro Latiné creatives use the arts to express their identities, ideas of resilience, and reliance on their ancestral past. They create works that are centered on firsthand experience or the shared experiences of their community. 
The tendency to center experience and shared values while claiming space for oneself is comparable to how Black Femme creators leveraged their specialized experiences and understandings of the world to inform their work, just as past music-makers like Mercedes Sosa and living students of the craft do, whether they are cognizant of this or not.

There is a common thread between the two populations which is demonstrated by how both Afro Argentine Femmes and Black North American Femmes understand their identity through their use of music. Femmes in both Black North America and Argentina intuitively understand their relationship to the society around them to be inherently antagonistic because of White supremacy. Both groups navigate the world through a fractured sense of consciousness and understand that their gender is determined by the successfulness of the individuals fractured manifestation of themselves in any given moment. This is not to say that Black Femmes understand themselves as somehow incomplete or inadequate, but it is to say that they understand themselves as having to perform many identities simultaneously. Black Femmes use music and their voices to reclaim space and to maintain their spirit of protest. There is a significant presence of maintaining a certain sort of spirit, or soul, within musical performance that is distinct, improvised, and irreplicable.

Black thinkers such as Patricia Hill Collins, Angela Davis, and bell hooks all have documented the epistemic value of Black music production for femmes throughout the African Diaspora. Music has tended to be viewed as a political act of protest and as a facilitator of Black radical consciousness of Black North Americans. The same can be 
said for Black Femmes in the global south, no matter how they define their blackness or femininity.

\section{Genre Is Insignificant, Mostly}

I was repeatedly reminded that, as far as Afro Argentines are concerned, they are more interested and have a respected presence that preserves their heritage. Genre does not matter. The only thing that matters is that Afro Argentine musicians are seen as creating art and culture, while reclaiming and sustaining the cultural products that proceed their current time and place. Afro Argentine punk artists participate in Punk culture because it's trendy right now. It seems that there is not much else to their reasoning.

Afro Argentines visibility within and outside of the American Diaspora is essential to Argentine radicalization, creating space for Black conscious raising. Centering celebratory spirit or the remediation of pain is truly a connection between the Black North American and Afro Argentines-regardless of genre. In an interview the Fredrico Pita of DIAFAR, he states, "Independientemente de qué tipo de música, nosotros [los negros] cantamos sobre las mismas cosas: divertirse, nuestra opresión, superar obstáculos y la familia. Eso es lo que es ser negro.

Regardless of what kind of music, we [black people] talk about the same things: having fun, our oppression, overcoming obstacles, and family. That's what being black is (Jones, 2018)." 
There is something to be said for the tendency for Black femmes, and individuals of the African American Diaspora at large, to utilize Blues, Folk, Jazz and Hip Hop as a forms of radical musical resistance. In Blues Legacies and Black Feminism, Angela Davis provides a genealogy of Black Femmes in Blues and through her exhaustive analysis of the key femmes in her genealogy, Davis suggests that is through musical genres like Blues and Rock and Roll that Black femmes have been able to create a foundation for a genre of music that celebrates sexuality, and a sense of cohesion through chaos through their innovative use of tones and timbre (1999). This experience can be treated as gateway to Black femme experience--a starting point for understanding. Blues is just one of the many vehicles that Black femmes have used to share their experiences with other Femmes. Davis' argument still holds, even when applied transnationally, as Afro Argentines like the historical figure Mercedes Sosa and the living musician Isabel have demonstrated. Patricia Hill Collins contributes to this discussion in her work Black Feminist Thought: Knowledge, Consciousness, and the Politics of Empowerment. In this work, Collin argues Black Femme identities flourish in spaces where the intersection of both Black and Femme can be explored in a non-adversarial manner and lived experience is centered. Collins argues that music allows for Black women to create these spaces that are not constrained by the limitations of time, geography, and linguistic barriers. Music is a sum total of a person and their experience with the musical moment (1990). Although Collins focuses on the Black North American population, her sentiments can be applied through the diaspora. The ineffable quality of Black femininity is conveyed through music for Black North American and for Afro Argentines alike. As suggested by feminist 
musician and historical figures such as Mercedes Sosa, Afro Argentines also utilize the same genres as a tool of resistance. It is, after all, the Black way of doing things.

The underground music scene in Afro Argentina is rich and preferences a pop-up style event planning with freely improved music. Because of this, there is very little record in the form of written lyrics. Many Afro Argentines do play in local shows with local bands, but it is noted that these Afro-Argentine musicians are often white-passing and typically downplay their Afro-Argentine identity to ensure that they are actually paid, paid fairly, and treated well within the venue space.

Afro Argentines are very proud of their extensive music networks. Typically, word of mouth is their primary way of promoting shows, outside of social media. Because of that, Afro Argentine music events are often exclusive Afro Argentine and operate as an autonomous music space. 


\section{CHAPTER 3}

\section{GLOBAL BLACK JOY AND AFROSONIC NOISE: AS SONIC EXPERIENCE}

Perhaps it is wise for me to explore the similarities between Afro Argentine Black Music and African North American Music in closer musicological detail using feminist praxis - after all my project lends itself to utilizing some sort of approach that is in part postcolonial cultural studies, autoethnographic, and part musicological that centers the femme experience. This is yet another crucial link that connects Afro Argentine musical contributions to the African Diaspora to my community in Black North America. I realize that this is no easy task for me. I am tasked to find a common link between 2 people groups that have come to know themselves through paralleling but colonially different environments who are creating their own histories and cultural products on opposite sides of the Americas yet still calling them Black music.

I have already discussed the post-colonial histories of Afro Argentine and their musical performances, products, and events that have contributed significantly to their musical history and political discourse. I have compared that experience with the Black North American experience in order to show that the histories parallel and intertwine. The next step is to take my analysis a bit deeper into a sonic-specific experience with the aim of taking a closer look at Afro Argentine underground music as one instance of performed cultural memory in the same way that Black North American music performs 
cultural memories centered on Spirit, or rather the soul, of a given musical performance. But how can music express cultural memory and identity with just the production of sound on a such transnational scale that African North Americans and Afro Argentines can share similar expressions of Blackness, even though it is defined and therefore expressed multivocalically?

It is very difficult to provide a rigorous analysis about a sound experience that vanishes as quickly as it manifests and is anchored in a shared sense of identity that is defined in many ways. Therefore, I use joy alongside traditionally explored musicological elements such as tone, timbre, rhythm chains, to create a sonic picture of community that builds upon my post-colonial exploration of both people groups. I use Black Joy’s musicologically essential element between Afro Argentine and Black North Americans, as Black Joy seems to be the true shared phenomenological element of identity between the distant communities as well as its antagonistic existence, protest, and resistance, which is not only fundamental to the performance of Black music in the diaspora but also as an analytic tool that is methodologically significant, relevant, and crucial to understanding the shared identities of Black North Americans and Afro Argentines as expressed through music. I narrow the scope of my investigation of Black Music to underground Rock music, although my work can be applied to Black American music as a whole.

I am less than thrilled to place some version of systematized analysis within my research. But I find that it may be a useful exercise in order to situate my otherwise aptly unstable and fluid transnational music performance study—for now—so that my inquiry becomes localizable enough to study musical sounds. Diana Taylor, an Argentinian 
performance scholar who primarily studies Latinx Cultures, provides a framework that can help in some sense stabilize my inquiry. In the first chapter of The Archive and The Repertoire, Taylor writes:

"Performances function as acts of transfer, transmitting social knowledge, memory, and a sense of identity through reiterated, or what Rich Schechner called “twice-behaved behavior”. “Performance”, on one level, constitutes the object/process of analysis in performance studies, that is in the many practices and events—-dance, theatre, ritual, political, rallies, funerals—-that involve theatrical, rehearsed, or conventional/event appropriate behaviors. These practices are usually bracketed off from those who around them to constitute discrete foci of analysis. Sometimes that framing is part of the event itself-a particular dance or a rally has a beginning and an end, it does not run continuously or seamlessly into other forms of cultural expression. To say something is a performance amounts to an ontological affirmation, through a thoroughly localized one. What a society considers a performance might be a nonevent elsewhere (Taylor, 2)”.

Taylor is offering invaluable insight here. She is arguing that a given performance- —of any sort—serves the audience in more ways than just being something of aesthetic stimulation. It is the retelling through living things that the community that surrounds a given performer has experienced. Performance is experiencing the past and the now coalescing forces that fuse the moment a performer begins. Because of this fusing, every performance can be understood on multiple axises. A work of performance, whether it be dance, music, art, or any of the examples that she had mentioned, 
"constitutes the methodological lens that enable scholars to view events as a performance” (Taylor, 3).

Taylor positions the body in a crucial way. She argues that the body is the site of great understanding of performance as it connects to the performer, performance, communal identity, and beyond. She contends:

"Civic obedience, resistance, citizenship, gender, ethnicity, and sexual identity, for example, are rehearsed and performed daily in public spheres. To understand these as performance suggests that performance also functions as an epistemology. Embodied practice, along with and bound up with other cultural practices offers a way of knowing. The bracketing for these performances come from outside, from the methodological lens that organizes them into an analyzable "whole”. Performance and aesthetics of everyday life varies from community to community, reflecting cultural and historical specificity as much in the enactment as the viewing/reception. Performances travel, challenging and influencing other performances. Yet they are situ: intelligible in the framework of the immediate environment and issues surrounding them. The is/as underlines the understanding of performance of performance as simultaneously "real: and "constructed" as practices that bring together what have historically been kept separate as discrete, supposedly free-standing, ontological and epistemological discourses (Taylor, 3).”

Taylor provides a framework that essentially connects a given instance of a performance as defined by the performers and the spectators as part of a larger performative narrative that is global. In studying one part of the performatively constructed narrative, we situate the whole both in sound, language, method of delivery 
and community that it arises from giving us a musical discourse. This is not an attempt to flatten the particularities of a given performance, but rather to treat these particularities of a given musical performance as perfect and a full participant in the shaping of cultural histories that do not recognize geographic boundaries.

Taylor’s new framework may not seem too terribly controversial to some. In fact, there are many studies of the transnational scope of music. However, they are often etched into musicological discourses through different textual notations that are deceptively universal such as historical retellings of musical performances and musicology study that centers on collecting and codifying musical accounts using standardized musical notations. However, Taylor specifically states that her investigation of performance is centered on performance as an embodied cultural memory that ought not be reduced to solely a cultural expression of text or historical narratives. Consequently, Taylor posits that, “This shift necessarily alters what academic disciplines regard as appropriate cannon and might extend the traditional disciplinary boundaries including practices that were previously outside their purview” (Taylor,13).

In order to call focus on the embodied acts, Taylor makes a distinction between The Archive and the repertoire. She reaches into the history of the Spanish conquests of the Americas to show that embodied praxis and the episteme of cultural performances is crucial. She prefaces her conversation by stating that Aztecs, the Mayan, and Incas all had practiced writing before the conquests, typically in pictogram form or some sort of knotting tradition. Their knots as well as their pictograms-all constituted a form of text with no particular primacy over the performed ritual itself. 
This is not to claim that their respective writing traditions were not valued at all. The opposite is true. But these people groups valued their texts as mnemonic aids to help with ritualized performances (Taylor, 14). The creation of these texts was a sacred task. It was given to specialists within the community. The most skilled created the codices that the community used to craft their ceremony (Taylor 14, 15). It was not until the Spanish colonization of the surviving peoples of the Mayan, Incas, and the Aztecs that they began to use text to codify history, accounting matters, and astronomy. which engendered the $t$ shift from part embodied performed and specialized ritual aid to a primary site of cultural transmission. As a result, there was a shift toward creating an archive. Archive was defined as the collections of textual products. The archive worked in tandem with repertoire. The repertoire allowed scholars to trace traditions and influences of people. The repertoire represents the intangible parts of cultural memory. It is a mode of storing and transmitting cultural knowledge.

Taylor offers a new sort of methodology that allows for considerations of both archive and repertoire of any given performance by what she terms as "scenario analysis”. Scenario analysis is just that: a means of understanding a given instance of a performance based on its archival and phenomenological contexts. There are six considerations for scene analysis. The first of these considerations features well investigated and theorized techniques such as literary analysis and historical observations to call attention to a particular place and time. This investigation ought to be executed with a meta-oriented attention that pays attention to the people that are part of the scenario as well as their corporeal behaviors such as their behaviors, attitudes, beliefs, and tones that are not reducible to language like music (Taylor, 28). 
This allows for the text and the repertoire to play freely with one another that is authentic and can capture the scene in its entirety. When a scenario is recounted, or reactivated, we conjure up the physical environment and the conditions of said place in a sort of eco-historical and existential way. Scenarios analysis includes pertinent information like social class, gender, sexuality and other social determinants in a given historical period. This is chiefly the role of the archive, although archive often functions in more ways.

The second consideration of scenario analysis is the embodiment aspects. This means that the researcher must grapple with the context in which their social actors perform and how their bodies function as performers as beings with socially constructed identities (Taylor, 29). This means that it is imperative to consider age, sex, status, external appearance, any person peculiarities of the performer and so on. Embodiment and performance can create a disjointed or tense relationship between dominant discourse and the narrative for the performers. However, the frictions between plot and character (on the level of narrative) and embodiment (social actors) make for some of the most remarkable instances of parody and resistance in performance traditions in the Americans, according to Taylor (31).

The third consideration centers on the use of formulaic structures that "predispose certain outcomes and yet allows for reversal, parody and change” (Taylor, 31). This element implies that the formulaic structure can in some ways be transformed, just as pictogram and hieroglyphs did for the Mayans, Incas, and Aztecs. The structure is coherent to not only the performer but to their social history and community in the context of how they have come to perform in a given place. According to Taylor, the 
transferring medium of any given scenario is durable, transposable, and yet is constantly adapting and responding to dominant sociopolitical power-just as the performers do.

Taylor argues that the fourth consideration is of the multifaceted systems at work in the scenario itself: in passing it on, we can draw from various modes if transfers come from the archive and/or the repertoire which includes writing, telling, reenactment, mine, gestus, dance, and singing (Taylor 31, 32). There are many systems that influence the manner of transfer when it comes to that of cultural memory. These systems should not be thought of in a hierarchical way, nor should they be thought of as any of the systems that take precedence over another. She admits that this is a tricky task because it is the general tendency to translate the embodied expression into a linguistic text or vice versa.

The fifth consideration calls into question how the researcher is situated in their relationship with scenarios as participants, witness, and/or spectators. Taylor argues that we need to present and “to be there” as part of the act of transfer. This consideration does mean that there are instances where the scholar is precluded to elements of a given scenario because they are not an intended participant nor audience.

Taylor calls our attention to her last consideration. She argues that a scenario is not necessarily, or even primarily, memetic (Taylor, 32). Even though Taylor acknowledges that there is a sense of continuity of cultural products, it often works, or has some sort of permanence, because of reactivation and not duplication. Scenario conjures up connected instances and past performances and situations that have been so profoundly internalized by a society that no one remembers the precedence, not in the sense of a copy of a performance but rather as a “one-again-ness” (Taylor, 32). 
Taylor's account has provided me with enough of a framework in order to do performative study which extends beyond a merely historical investigation between Afro Argentine and Black North Americans to a musicological investigation, which emphasizes an embodied ethnomusicological and performative framework. I intend to take Taylor's framework to its possible limit by threading joy, or the mimicry and parody or irony of joy, as part of embodied cultural memory that has ethnomusicological value. On a global scale, the music that African descendant peoples perform is a true instance of once again-ness. Blackness as mediated by music to convey our cultural memory that is bound by the play and its subsequent joy—regardless of if that joy is conveyed through, irony, paradox, parody, or some other form.

What is also crucial is that Taylor's theory is applicable to marginalized communities that have not participated in dominant discourse. And indeed, Taylor's concept for cultural memory that is extremely palpable to Black North American feminist episteme of performance as well as the burgeoning episteme Afro Argentine performance as a hybrid of both Latinx and Black performance.

The scenario of which I have already laid significant archival information on Afro Argentine femmes in music in the previous chapter of this project. I have introduced some Afro Argentines who represent different groups of social actors in the cultural memory of music performance-which is required of me if I stay true to Taylor's model. I have also explored how musical performances have been taught to other member of the Afro Argentine community through specific acts of mediate acts of transfer like payadas, liturgical music, underground musical scenes, and Afro Argentine Nuevo Cancionero Movement which is akin to the Black Arts Movement in North America. 
Further, I have connected Afro Argentine music and history to African North American musical history through a shared sense of struggle and resistance. I have situated myself and experiences in Afro Argentina as central to my understanding, and lack thereof, of Blackness in the global context. I will now explore the elements that are more firmly planted in the repertoire: the sonic elements of Afro Argentine music using musicological elements such as rhythm, timbre, texture, tone, and Black Joy, which is the final performative consideration I will explore in this work. Daphne Brooks provides a critical Black Femme ethnomusicological methodology that is essential to my work. In Afro Sonic Feminist Praxis: Nina Simone and Adrienne Kennedy, Brooks provides a framework that elucidates Black femme-ness as musical phenomenon that is embedded in the dimensions of the Black polyphonic experience which creates an "afro-sonic feminist noise”. Brooks defines afro-sonic noise as;

"a kind of sound composed of heteroglossic gestures that articulate "the ability to speak

in diverse [musical] languages” here, as well as glossolalia and a desire to forge, maintain, and take pleasure in a black women's musical subcultures that is outside

the realm of public discourse and foreign to the known tongue of mankind (Brooks,207)”.

Brooks statement is a potent one in that she is arguing that afro sonic noise are multivocalic due to their heteroglossic nature, which quite literally means that they contain the presence of 2 or more voices or that they express some sort of duality of identity or viewpoints within a given work, and therefore can be defined in numerous ways. For Black femme aligned individuals, often this afro sonic noise is often conjured 
through the expression of what seems to be nonsensical sputtering of tones that often readily speaks to the ineffable, yet shared identity of being Black and being femme. Afro Sonic noise is black joy's glossolalia—which is roughly defined as a phenomenon in which people speak in languages unknown to them and in some cases as part of religious practice in which it is believed to be a divine language unknown to the speaker and can be readily identified as "speaking in tongues", or in musical terms that improved music such as a breakdown in a rock song or improved jazz music and is perhaps the best word that Brooks could have chosen for afro sonic noise. Afro sonic Fidelity is a mode of transfer for embodied Blackness that is recognized as the spirit, the soul, of Black music.

Through the careful reconstruction of her genealogy of Black Femme expression in "high afro-sonic fidelity", Brooks goes on to state that, "sonic blackness is a perceptual phantom projected by the listener; a vocal timbre that happens to match the current expectations about blackness; or the shaping of vocal timbre to catch current ideas about the sound of blackness” (Brooks, 219).

Brooks offers more insight into afro sonic noise when she also claims that, "through a kaleidoscope range of dramatically contrasting qualities of sounds, through a "fundamental bias for contrast of color" and a "usage of a diversity of vocal nuances", Black Music often privileges a "musical texture in which individual's voices are discerned within a mass of sound” (Brooks, 207). In Brooks’ account, voice is very specifically referring to vocalized noise that is produced from a human body, but it is not limited to this context. Indeed, instruments have voices—and these voices are excluded from Brooks' accounts as they have musical texture and are distinct. Brooks makes it clear that she is most interested in how different voices are found within music by 
asserting that,, " [the] signal and riff upon the presence of blackness as excess and excessive presence in the musical and discursive operations of black female producers" (Brook, 208).

The very last piece of my musicological puzzle comes from Fred Moten, poet and performance studies professors at New York University, who provides us with a more robust and systematically musicological explanation of what Brooks terms as 'afro sonic noise’. In his work Chromatic Saturation, Fred Moten contends that;

"In this regime of uncut musical differences...in which regulation and resolution are render spectral im/possibilities, in which "all the notes" are present, let's call the other version of chromatic saturation black/ness so to be overrun by metrical promiscuity, by profligate madrigal, by accidental, unwritten black notes. In music, blackness indicates chromaticities a potentially unregulated or profligate internal difference, and impurity from the mixture of modes (major and minor) or of the scales (diatonic and chromatic); it can be situated between an unwritten but aurally performance abundance or improvisational excess derived from textual implication or a kind of visual overload of black marks on the page” (Moten, 9,10,12).

Simply put, Moten is saying that there has been this overarching discursive tendency to flatten or assimilate musical differences. This comes in a form of musical regulation in which resolutions create something close to a spectrum of unachievable possibilities and the impossibilities potentially achieved. In this spectrum every note can be voiced. This spectrum is considered filled with space for voiced notes—regardless if 
they are actualized or not. All these notes are interacting with one another in some sort of chromatic saturation or notes that fall outside or in between a definable scale.

Blackness is expressed in the mist of this seemingly chaotic or otherwise unruly sound production. It is antagonistic to dominant musical metrics. In some ways, Blackness as it is expressed in music is more akin to unbridled madrigal, or operatic, vocalizations which run in and out, to and from, around and within, a chromatic space. The cacophony of black sound is profligate, meaning it is extravagant. It is bold and brazen. Often produced with an exacting clumsiness. It subverts what is to be considered stand modes and sounds and creates a sense of a sonic texture that is explicit to the instance of its production as it is largely improvisational that is irreducible to "black marks", musical notation, or as I can imagine Taylor would say—-the embodied archive of from which this sound emanates.

I am excited to extend this dialogue to make sense of what I have come to learn about Blackness as it is expressed by femme individuals in underground rock music in Black North America and Afro Argentina—and more broadly Black Diasporic music across the Americas. I am most excited, however, to further argue that afro sonic noise is the shared ethnomusicological and phenomenological significant link between North Back American and Afro Argentine music because it is African diasporic cultural memory voiced and embodied that forages a sense of a global community—mostly because this is my unique contribution to this discourse.

One of my first contributions to this dialogue will be to argue that Afro Sonic noise is a global phenomenon. Afro sonic noise is not exclusive to Black North American music, nor does it depend on a strict definition of Blackness. It only requires vocal 
production from African Diasporic bodies, both animate and inanimate. Afro sonic noise is chaotic sound. It is the very sonic that conjures a sense of irony, pain, resistance and community, which are all bound together in the understanding of blackness and therefore Black joy. Afro Sonic noise is Black Joy.

To claim that Afro sonic is a global phenomenon is important, and yet is still taken for granted, but ultimately it is an unimpressive claim as it is quite clear that African descendent peoples exist across the globe. It is equally unimpressive to claim that they have created cultural products. However, what is of note is how these products connect to personal liberation, resistance, and embodied expressions of blackness as well as a recognizable and authentic tonal quality. This I claim I have yet to explore in a tangible way, but plan to in later work.

My second contribution to this body of work to provide a more in depth exploration of two black Femme who seem to embody the expression of Black Joy through their music because Afro Sonic Noise is found within the legacies of African Diasporic music in Afro Argentina and Black North America—especially in their respective underground music histories. Although there is no standardized set of criteria for identifying said sound, as afro sonic noise nor Black Joy are reducible in such a manner, I can in part attempt to capture how afro sonic noise is exemplified in Afro Argentine underground music and in Black North American rock music by using work of Rita Montero and Elizabeth "Libba” Cotton.

Rita Montero is one of the first Afro Porteñas who was "una actriz, cantante, activista” (Cirio,1). According to Montero, her family are the direct descendants of enslaved africans who were transported to Argentina specifically by Guillermo Brown, an 
Irish-born Argentine admiral, in the mid 1800’s (Montero and Pablo Cirio, 18). Born in Palermo Buenos Aires in 1928, she was surrounded by music. In Rita Montero, Memorias de Piel Morena: Una Afro Argentina en el Espectáculo, she claims that music was in her blood, due to her father's musical ability and access to musical instruments. She recalls that her father often sang together.

In Rita Montero, memorias de piel morena : una afroargentina en el espectáculo, when asked about a El Santo which is a song that she learned from her father's cousin, she was told that this particular song, which is traditionally sang as part of a candombe ceremony was "something that I would sing and sing and dance and dance to, but there was something that was African about it that I didn't know what it was (Cirio, 28)”. She mentions that she felt a special connection to the end of the song because her family told her that the last part is sung in “Africano”, a term that Afro Porteños use for the creolized african language that is mixed between unspecified African dialects but does not demonstrate any linguistic mixing with Castilian Spanish. Montero admits that initially she did not know that Africano existed, nor that she was singing in it (28). In the interview she sings the tune, with Africano emphasized at the end of the verse:

Dondé está la llave?

De la mesa 'e luz?

Y si querés saber

Preguntarle Casú

Caracasú, casú, casú (Cirico, 29). 
It is important to note that Africano was specifically an Afro Argentine musical language, as it is found almost exclusively in songs. According to Cirico,

“Cantar en Africano es una expresión empleada por afroporteños para referirse al repertorio de canciones más antiguo vigente. Coinciden en vincularlo al período esclavista en el país o, inclusive, que fue gestado en África. Está integrado por una docena de cantos y sus rasgos principales son: compás binario, estructuración melodías en base la fórmula 3: 3: 2, ámbito reducido, melodía neumática, y aparición de la forma responsorial. Sus textos son más bien y brevas y en lenguas africanas hoy desconocidas por los afroporteños, por lo que los cantan (a cappella o con acompãnamientos de tambores) de acuerda a fonética comunalmente consensuada (29)".

["To sing in African is an expression used by Afro Porteños to refer to the oldest repertoire of songs in force. They assign these songs it to the slavery period in the country, or even that it was made in Africa. It is integrated by a dozen songs and its main features are: binary compass, melody structure based on formula 3: 3: 2, reduced scope, neumatic melody, and appearance of the responsorial form. Their texts are rather brief and in African languages now unknown to Afro Porteños, so they sing them (a cappella or with drum accompaniers) of communally decided phonetics.”]

Africano featured musicological elements that are typical of African diasporic music: polyrhythmic, heteroglossic vocalizations which in this case translates into ethereal sound or sound that sounds processes a certain spirituous yet sensical sound, and is performed through audience participation in a call and response form. 
Montero maintained her familial traditions throughout her career . She often attributes her success as vocalist and actress to her commitment to preserving her roots while integrating new techniques that she learned from María Naftri, her ItalianArgentine vocal coach. a vocalist and actress to her commitment to preserving her roots while integrating new techniques that she learned from María Naftri, her ItalianArgentine vocal coach.

Montero claims that her integration of africano elements to her jazz performance "was the only thing that she had to stand out" and that "she was happy to share a tradition that she learned with others who were willing to listen” (Cirio, 31). Montero revolutionized Argentinian jazz and opera by integrating Africano, call-and-response, and a certain sort of distinctly Rita playfulness and spirit into her performances.

She also interpreted many other Afro Argentine art forms for popular consumption. She often performed Tango and Jazz works in coffee houses, bars and speakeasies as well as other night clubs. She traveled across South America, namely in Buenos Aires, San Juan, Tucumán, and Santa Fé, Montevideo, Santiago de Chile, Lima, Porto Alegre and Santo Pablo. In 1961, Montero recorded three album albums for RCA Victor with Tangos de Piel Morena and Carlos Garcia Orchestra ( Leguizamon, 2).

In a seemingly paralleling timeline, significant musical advances were made in Black North America. Elizabeth Cotton was born in Chapel Hill, North Carolina in 1891 (Southern, 220) to George and Lisa Nevills who could not agree on a name for Elizabeth. George and Lisa Nevills never gave Elizabeth her first name. Elizabeth named herself on her first day of elementary school. She is said to have told her first-grade teacher that her 
name is Elizabeth because she likes the way the name sounds when spoken aloud (Carley, 2000).

Cotton is noted for playing her guitar upside down due to her left-handedness. Her non-traditional playing style allowed her to play both a bass line and a guitar part at the same time. In one piece, with her single instrument, she produced the sound of 2 distinct musical voices from one instrument. She managed to attain heteroglossia on a guitar. Cotton's technique is considered a standard in American Rock and Folk music as it achieves a fullness of sound that allows for play spiritedness and motion that is so characteristically found within these two related genres.

Cotton and Montero are just two examples of a global phenomenon of combining African heritage, current struggle and a sense of bringing a Joyful noise that is chaotic and spirited through their performances whether it was vocal or instrumental. They both break conceptions of what is musically and conceptual possible by and through some sort of technical advancement as in the case of Cottons who literally played her guitar upside while creating 2 distinct voices that resembled sounds coming from 2 very different instruments. Or preserving diasporic musical form and language as Montero did. Nonetheless, in their own way, their art exhibits a common thread-which is afro sonic noise.

American Black identity, as mediated through musical experiences, is ultimately irreducible to any musical annotation, musical event, or music-maker throughout the African American Diaspora. It is ever-evolving. Afro sonic noise relies on the history and shared experience of oppressions and resistance as an embodied knowing and leveraging this perception to ignite their unbound imagination to create musical acts of defiance. It is 
informed by communal understanding and interpersonal relationships with their ancestral, familial, religious, secular, and socio-political environments that shape the everyday life of the musicians who produce it.

Afrosonic noise, as expressed across the African American Diaspora, is not reducible to any one part of its production. Black sound is more than just the musicmaker who produced it, it's reception, recorded history, politics of the community that created it. Afro sonic noise is more than what can be annotated using standard musical notation. Black sound is the sum total of all these parts as an inseparable whole.

Conceptions of Black identities change as borders change, Afronsonic noise as expressed by different musicians from various communities of the African American Diaspora. In the same way, musicians use different instruments, or perhaps, different genres to express themselves. Regardless of the genre, Black communities across the Americas create defiant, resilient, notably rule-breaking and improvisational music that blends their voices with the collective noise of the Black collective cultural memory. Although it is hard to annotate or recapture the exact experience of Black sound, it is something that can be heard recognized. 


\section{CHAPTER 4}

\section{A STRANGER SEES ONLY WHAT SHE KNOWS: LIMITATIONS OF TRANSNATIONAL MUSICOLOGY}

I conducted six oral histories. While oral histories are celebrated for their ability to empower community members to retell their respective histories as they have lived them, oral histories rely on the memories of the narrators. People are experts of their lived experience; however, our memories are rarely perfect. The implications of this are reflected in the accuracy of memories which are often muddied by personal biases, objectives, and motives. And with no doubt, the effects of systemic racism are real. It is felt immediately physically, emotionally, and sometimes spiritually. And because there were only a few orators, there was a lack of age diversity among the narrators that could have acted as a sort of protection against generational biases. The orators were somewhat skewed, being mostly on the younger side, ranging from 23 years of age to the oldest orator being in their mid 40s. The exception to this was Maria who was in her 90's. While their narratives were rich, the generational gap between the Afro Argentinian individuals that I interviewed led to some conflicting ideas of gender roles and how to define Blackness.

Some may argue that experiences may belie or otherwise skew my informant's

ability to reproduce an accurate history of their people-especially since such history is so riddled with mass genocide. However, the orations were corroborated by general historical research provided by credible and Argentina-specific resources. The questions 
that I had prepared regarding race and gender did not easily nor readily translate to the Afro Argentine context. This was mostly due to the language barriers as I have mentioned above. However, some of the confusion was inevitably due to the implicated imperialistic understanding of what Blackness is, which was pointed out in numerous ways with comments like "Your idea of Black is broken”( Jones, 2018).

Regardless, all definitions seemed to hint at a mistrust of the Black North American experience-but the degree of mistrust was significantly higher in Maria, the oldest orator and Isabel who was the youngest. Those who were late 20's to mid 40s seemed to have the most consistent idea of Blackness and gender. Questions of race and gender expression through music could have produced emotions that may have interfered with a person's ability to recall personal details of their lives and communities. The tricky thing is — my own embodiment as a Black North American identified person as well as the filter of all of my experience, even the sonic ones, seemed to be the very identity that produced the distrust and this sense of alienation. This could have led to a stronger urge to disidentify with Blackness as they assumed that I was in some way challenging the way that they thought about themselves in relation to a monolithic idea of Blackness.

I have realized that research method of ethnography, and by extension ethnomusicology, is deeply flawed in that even though I tried my best to avoid the pitfalls of ethnographic inquiries, it was still essential for me to highlight the shortcomings of ethnography—which served as an anchor for the ethnomusicological study and social histories in order to adequately acknowledge and account for these shortcomings. I focus this section primarily parsing out concerns regarding ethnographic musicological study, belonging and identity to a socially colonial identity, ownership of cultural products, the 
relationship between artist intent and the work itself, and accuracy and authority of a first-person centered line of inquiry.

Perhaps the most painful of the limitations are out of the social identities associated with me-as my concepts of femme-ness, blackness, and social importance of music somewhat failed to translate to my respondents. Although I was committed to framing the heart of my inquiry, which is performance based, and although I situated a recounting of Afro Argentine social history and Afro Argentine experience within the context of Black North American Rock and Roll history. I inevitably drew mostly on the knowledge of Blackness, rock and roll, concepts of underground, femme-ness that I was familiar with. Thus, by me using my own self as the epistemological starting point and my own participation in and familiarity with this narrative as well as my own sense of the socio-cultural musical ownership, I affixed Afro Sonic Noise within my own understanding of self-expression and liberation. Directly connecting it to my own personal experience even though I also posited it on a transnational scale and got to stay in Buenos Aires for a short while. This affiliation led me to a paradoxical relationship between the musical performance of the personal and/or communal identities to the localization of a diasporic and the globalization of diasporic musical products.

\section{We See What We Know}

Every effort of transnational exploration requires a unique sort of consideration between global and local identities and the politics of their formation. Identity, then, requires that on some level individuals belong to a collective that shares a sense of 
communal beliefs, art, religion, and customs. This sense becomes embedded in how we perceive the world around us as contextualized by the geographies of our designated home-place, communities, cities, countries, and beyond. Of course, as we travel, our sense of identity travels with us. We understand our new experiences, wherever they may be and with whomever may be around, through this understanding of identity twe are constantly refined. We even understand what art is, what is beautiful, what is artistically meaningful and culturally significant through our understanding of our identity.

Researchers that share diasporic identities—yet understand the significance of a performance as art in the context of a different set of expectations and cue of aesthetic values—run the risk over-assigning value to performances that the community from which they come may otherwise find barely significant or significant but otherwise inconsequential in their contribution to the cultural narrative of the local community.

Musical Anthropologist Laurent Aubert offers insight on the entanglement of identity, community, and music both locally and globally in their work entitled The Music of The Other. Laurent posits that;

"The question of identity is place simultaneously on the collective level with 'objective' components such as adherence to a civilisation, religion, community, ethnicity, social class, age, political party and so on) and on the individual level (with 'subjective' components—-how individuals situate themselves in relation to these components. Far from being insignificant, the problematic of identity is perhaps one of the most challenging [problem] that we must face; it is at the source of the schisms and the most serious conflicts generated by the present postcolonial period. (2).” 
Here lies the problem. Laurent is right to assert that identity poses a seemingly insurmountable task to the study of music and the cultures from which they came. There is truly no understanding that hinges on any sort of 'objective' metric. And while there is a genuine entanglement of civilization, race, religion, social class, and other social determinants, we cannot readily understand them without the concept of the colonial space of which they inhabit. Identity is crucial to the study of music and is just as unstable and instantial as its performance.

The troubling part of identity is that people tend to carry notions of their identity with them as we navigate the world. I am not excluded from this tendency. And by unfortunate consequence, I also ran the risk of imbuing my own sense of significance, meaning, and epistemological understanding of culture, its memory, and the processes which in turn ran the risk of perverting the significance of them. Or I run the risk of assigning undue meaning when I encounter and seek to understand a different community's music. I am potentially liable for this error because ethnography, and ethnomusicology by extension, is counter-productive to postcolonial efforts, due to their reliance on the racist ideology that Black North American identity has been constructed as an antagonist to White American culture. The margin of error exponentially increases when the geographic distance does which requires a transnational critical framework.

In an effort to avoid the pitfalls of ethnography, I have taken a participatory approach when possible. While my questioning did not flow as flawlessly as I had planned, I provided room for the living music-makers and community members to define what their identities mean to them. I allowed the narrators to draw connections within the Afro Argentine social history that they knew to be true. I have co-created this project in a 
way. I intentionally included my 6 living orators during the editing process, giving room for the orators to correct any misunderstandings I may have of the information they have provided me. I have adjusted my language around identity and significant historical figures accordingly. I used textual evidence of identity when referring to historical musicmakers.

\section{Music Is Changing}

My work focuses on music-makers who primarily relied on live performances to showcase their works. Many of the Femmes and women featured in this project were also recording artists, but producing records was often considered inessential to the songs they wrote nor did the recording inform their musical performance. The record was just a means of mass distribution and preserving their work.

However, music is increasingly becoming digital. It relies heavily on the featured musician and sound engineer to craft records. There is less emphasis on crowd participation or improvisation. I have only considered Afrosonic noise for live performances of underground Afro Argentine music and popular Black North American music and have not considered the implications of modern sound engineering and the changing public consumption music that trends towards digital music.

I have also not taken any consideration of the role of the sound engineer while expanding upon Afrosonic noise. The sound engineer, even for live productions in theatre or in arenas, often make stylistic choices that impact the way the audience consumes music. The sound engineer is assisting and refining sound as the musician performs. This 
means that the sound engineer plays a large role in creating a musical work and is also contributing to the timbre and other sonic qualities of a given song.

I have crafted this project as a work that brings Black Femme music-makers across the America together using Black Feminist t methodology. I share what I learned from my time in Buenos Aires, Argentina from Afro Argentine music-makers and community activists in an attempt to not only show the affinity between Black North Americans and Afro Argentines through shared struggles, identity, and musical expression but to also demonstrate that there is more to Black music than the conditions from which they arise. There is something that is unique to the sound of Blackness, Afro sonic noise, that is distinct and musicologically identifiable. 


\section{REFERENCES}

Alverez, María. Interviewed By Jerika Jones. Oral History. Buenos Aires, May 28, 2019.

Andrews, George Reid. Afro-Latin America, (Harvard University Press: 2004).

Andrews, George Reid. Afro-Latin America: Black Lives (1600-2000). (Harvard University

Press: 2016), 23.

Argentinos de origen africano, 135-40; Ildefonso Pereda Valdes, Antología de La Poesías Negra

America. 1990.

Beneméritos, Jorge Ford, 113-17. See also Pasada ”Las Poesías del Joven Thompson”, 3.

Little, Cynthia J., Marifran Carlson, and George I. Blanksten. “|Feminismo! The Women's

Movement in Argentina from Its Beginnings to Eva Peron.” The American Historical Review 95, no. 2 (1990): 633. https://doi.org/10.2307/2164006.

Brathwaite, Edward Kamau . Roots, 211.

Brooks, Daphne A., “Afro Sonic Feminist Praxis: Nina Simone and Adrienne Kennedy”. Black

Performance Theory. Duke university Press, 2014. 
Cirio, Norberto Pablo. Afro-Argentine Music: Notes for A Social History of Silence, (National

Institute of Musicology: Argentina: 2015), 116.

Collins, Patricia Hill. Black Feminist Thought: Knowledge, Consciousness, and the Politics of

Empowerment. Routledge, Taylor \& Francis Group, 2015.

Crenshaw, Kimberle. "Demarginalization of The Intersection of Race and Sex: A Black Feminist Critique of Antidiscrimation Doctrine, Feminist Theory, and Antiracist Politics."

Davis, Angela. Blues Legacies and Black Feminism. New York (NY): Vintage, 1999. Dreisbach, Spencer. "Willie Mae "Big Mama" Thornton." Encyclopedia of Alabama. June 13,

2008. Accessed September 1, 2018.

http://www.encyclopediaofalabama.org/article/h-1573.

Finn, Julio. Voices of Négritude, Preface. 1997.

Friegerio, Alejandro. Outside the Nation, Outside the Diaspora: Accommodating Race and

Religion in Argentina.(Sociology of Religion, 2002).

George-Graves, Nadine. “Diasporic Spidering: Constructing Contemporary Black Identities”.

Black Performance Theory. Duke University Press, 2014. 
“Isabel”. Interviewed by Jerika Jones. Oral History. Escuela de Musíca de Buenos Aires, Buenos

Aires. May 22, 2019.

Jorge,Angela. The Black Puerto Rican Women in Contemporary America, (Duke University

Press, 2010), 182.

Karush, Matthew B. Blackness in Argentina: Jazz, Tango, and Race Before Péron. (Oxford

University Press:2012), 217.

Kunst, Jaap. Ethonomusicology: A Study of It's Nature, its Problems, Methods, and Representative Personalities to Which Is Added a Bibliography. 3rd ed. Amsterdam: Hague.

Laurent, Aubert. The Music Of The Other: New Challenges for Ethnomusicology in a Global

Age. Place of publication not identified: ROUTLEDGE, 2017.

Láo-Montes,Augustin . Afro-Latinidades and the diasporic Imaginary, (Iberoamericana Editorial

Vervuert, 2005),118.

Lewis, Marvin. Afro Argentine Discourse: Another Dimension of the Black Diaspora.(University

of Missouri Press, 1995). 
Mahon, Maureen. "Mama's Voice". Rock \& Roll Hall of Fame. Archived from the original on

December 21, 2014. Retrieved November 2, 2019.

McClintock, Anne. " 'No Longer in a Future Heaven' : Gender, Race, and Nationalism," in

Dangerous Liaisons: Gender, Nation, and Postcolonial Perspectives, eds. Anne McClintock, Aamir Mufti, and Ella Shohat (Minneapolis:University of Minnesota Press, 1997). 10.

Mignolo, Walter D. "Epistemic Disobedience, Independent Thought and Decolonial Freedom."

Theory, Culture \& Society. 26, no. 7-8 (2009): 159-81.

doi:10.1177/0263276409349275.

"The Roots and Definition of Rock and Roll." Rock \& Roll Hall of Fame.

Accessed September 21, 2018. https://www.rockhall.com/roots-and-definition$\underline{\text { rock-and-roll }}$

Moten, Fred. In the Break the Aesthetics of the Black Radical Tradition. Minneapolis:

University

of Minnesota Press, 2003.

Pita, Frederico. Interviewed Jerika Jones. Espacio Malcolm, Villa Crespo, Buenos Aires. May

23,2019.

Republica Argentina, Institutio National de Estadistíca y Censos, 2010.

Riveria-Ridaeu, Petra. Afrolatin@s in Movement: Critical Approaches to Blackness and 
Transnationalism in the Americas,(New York : Palgrave Macmillan, 2016)12. Slavery In Argentina-Latina America," Slavery in Argentina - Latin American Studies Oxford

Bibliographies, June 19, 2019, accessed July 01, 2019, https://www.oxfordbibliographies.

com/view/document/obo-9780199766581/obo-9780199766581-0157.xml.

Schiavio, Andrea et. AL, Enacting Musical Emotions, Sense-Making, Dynamic Systems, and

The Embodied Mind. (Journal of Phenomenology and Cognitive Science, 2017). 16:785-809 DOI 10.1007/s11097-016-9477-8.

Sosa, Mercedes, Duermíte Negritos, El grito de la tierra, 1973, Vinyl.

Spörke, Micheal. "Big Mama Thornton: The Life and Music". Mcfarlandbooks.com. Retrieved

October 18, 2019.

Taylor, Diana. “Acts of Transfer”. The Archive and The Repertoire. Duke University Press, 2003.

Thompkins, Cynthia and David William Foster, Notable Twentieth Century Latin American

Women,(Greenwood Press, 2001),318.

Weather, MaryAnn “An Argument for Black Women’s Liberation as a Revolutionary Force”

158-155. 
Wallace, Michelle. “Anger in the Isolation: A Black Feminist’s Search for a Sister”. 220 $-227$.

Wynter, Sylvia. Race, Discourse, And the Origins of the Americas: A New World View. Smithsonian Institution, 1995. 


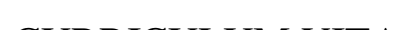

NAME:Jerika M. Jones

ADDRESS: Department of Women's, Gender, and Sexuality Studies

University of Louisville

Stevenson Hall, 320

University of Louisville

Louisville, Kentucky 40292

DOB: Aurora, Colorado- September 6th, 1990

EDUCATION \& TRAINING:

BA in Philosophy, social science concentration

University of Louisville

2010-2014

BA in Psychology, social science concentration

University of Louisville

$2010-2014$

MA in Women’s Gender, and Sexualiy Studies

University of Louisville

2018-2020 